- The lower section of the equatorial Atlantic mantle lithosphere is dominantly fertile

- Microstructures and textures record high-temperature deformation followed by variable degrees of annealing and melt-rock interaction

- Thermal models and seismic anisotropy imply a 75-90-km-thick plate with frozen CPO formed by horizontal shear in the asthenosphere

Supporting Information:

- Supporting Information S1

- Table S1

- Table S2

- Table S3

- Table S4

Correspondence to:

S. Liu and A. Tommasi,

hbhslsr@gmail.com;

andrea.tommasi@umontpellier.fr

Citation:

Liu, S., Tommasi, A., Vauchez, A., \& Mazzucchelli, M. (2019). Deformation, annealing, melt-rock interaction, and seismic properties of an old domain of the equatorial Atlantic lithospheric mantle. Tectonics, 38, 1164-1188. https://doi.org/10.1029/2018TC005373

\section{Deformation, Annealing, Melt-Rock Interaction, and Seismic Properties of an Old Domain of the Equatorial Atlantic Lithospheric Mantle}

\author{
Shiran Liu ${ }^{1,2} \mathbb{Q}$, Andréa Tommasi ${ }^{1}$ (C), Alain Vauchez ${ }^{1} \mathbb{C}$, and Maurizio Mazzucchelli ${ }^{3}$ \\ ${ }^{1}$ Géosciences Montpellier, CNRS and Université de Montpellier, Montpellier, France, ${ }^{2}$ Key Laboratory of Orogenic Belts \\ and Crustal Evolution, School of Earth and Space Sciences, Peking University, Beijing, China, ${ }^{3}$ Dipartimento di Scienze \\ Chimiche e Geologiche, Università di Modena e Reggio Emilia, Modena, Italy
}

\begin{abstract}
We analyzed a set of mantle xenoliths from the Fernando de Noronha archipelago to constrain the roles of deformation, cooling, annealing, and melt percolation in the evolution of the mantle lithosphere of the equatorial Atlantic. The peridotites are dominantly lherzolites with coarse granular or porphyroclastic microstructures. Equilibrium temperatures range between 850 and $1,000{ }^{\circ} \mathrm{C}$. Olivine crystal preferred orientations (CPO) have mainly orthorhombic patterns characterized by clear [100] and [010] point maxima or a fiber-[100] tendency; these patterns imply deformation by dislocation creep with dominant activation of the [100](010) slip system. Olivine fiber-[010] patterns are less common; they probably result from recrystallization or melt-rock interaction. Annealing after deformation partially recovered the microstructures and reduced the olivine CPO strength. Pyroxene CPOs often have weak consistency with olivine CPO, implying post-deformation refertilization. Chemical compositions are systematically more fertile than those from abyssal peridotites from the Mid-Atlantic Ridge. These compositions together with the microstructures suggest two stages of melt-rock interaction. An early refertilization of the base of the lithosphere due to continuous percolation of small melt fractions and later, more important, but local chemical changes (both refertilization and dunitization) as well as recrystallization due to reactive melt percolation likely associated with the Cenozoic volcanism. By comparing the calculated seismic properties with existing seismological data we argue that the moderate seismic anisotropy displayed by the Fernando de Noronha mantle xenoliths likely records past horizontal asthenospheric flow parallel to the spreading direction frozen in the lithospheric mantle as the plate cooled.
\end{abstract}

Plain Language Summary We studied a series of mantle rocks carried to the surface by the recent ( $<10$ Myr old) volcanism that formed the island of Fernando de Noronha on the top of 100-Myr-old crust in the equatorial Atlantic. The study of this natural sampling of a deep section (50-70-km depth) of an oceanic plate brings constraints on the processes involved in the construction and evolution of an oceanic plate as it cools and thickens with time. We analyzed the composition, microstructures, and orientations of the minerals that compose these rocks. The results imply that most of the deformation occurred at the base of the plate in response to the difference in motion between the plate and the convecting mantle. The resulting microstructures and crystal orientations were then frozen in the plate by cooling. Our data also support a change in the composition of the rocks that compose the mantle section of the oceanic plate, after their incorporation in the plate, by reactions with percolating magmas that most often increased their fertility (capability to melt).

\section{Introduction}

Oceanic lithospheric mantle is generally believed to develop by progressive cooling and accretion of asthenospheric mantle as the plate ages (Turcotte \& Schubert, 2014). It should therefore have a simple structure, with ridge-related processes recorded in its shallow levels and frozen asthenospheric compositions, microstructures, and crystal preferred orientations in its deep portions, unless disturbed by plume-related processes (Hess, 1964; Rümpker et al., 1999; Tommasi, 1998). However, reactive percolation of melts from the asthenosphere into the base of the lithospheric mantle and their crystallization may progressively modify the composition and microstructures of the peridotites in the lithospheric mantle (e.g., Le Roux et al., 2007, 2008; McKenzie, 1989). If this process occurs in a continuous manner as the 


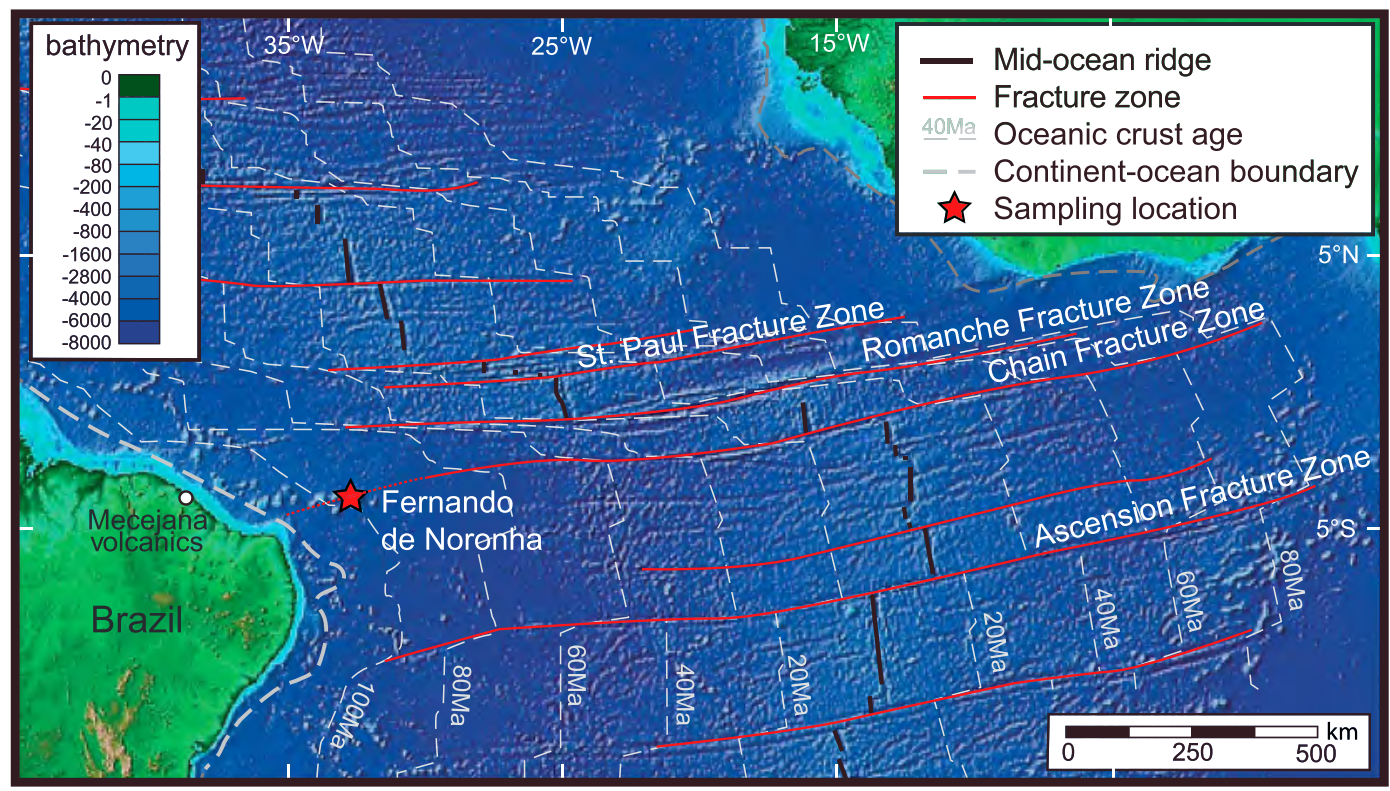

Figure 1. Topographic map of the equatorial Atlantic with major structural features and oceanic crust ages based on magnetic anomaly data. Sampling location is indicated by the red star. The topographic map is based on GTOPO30 DEM data generated in Jules Verne Voyager (http://jules.unavco.org/) using Generic Mapping Tools (GMT; http://gmt.soest.hawaii.edu/; Wessel \& Smith, 1991). Oceanic crust ages and COB are modified after Nemčok et al. (2013). COB: Continent-Ocean Boundary.

plate cools and thickens, it may affect most of the oceanic plate thickness, leading to compositions different to those of the shallow levels. Yet the characterization of the oceanic lithospheric mantle composition and microstructures is largely based on the analysis of abyssal peridotites and ophiolites, that is, on sampling of shallow sections of the plates. Direct sampling of the deep sections of oceanic lithospheric mantle is limited to xenoliths brought by oceanic islands volcanism.

Here we investigate a set of mantle xenoliths from the Fernando de Noronha (FN) islands (Figure 1), which sample the lithosphere of an old domain of the equatorial Atlantic. The equatorial Atlantic was the last section of the Atlantic to open at the Albian-Aptian boundary ( $113 \mathrm{Ma})$, connecting the central Atlantic and South Atlantic Oceans. This last stage of separation between the African and South American plates is accompanied by EW strike-slip motion in a series of fracture zones, such as the St. Paul, Romanche, and Chain Fracture Zones (Heine et al., 2013; Moulin et al., 2010; Nemčok et al., 2013). We analyze the microstructures, compare comparing the composition of the xenoliths to data on abyssal peridotites collected from Mid-Atlantic Ridge (Warren, 2016, and references therein) and correlate the seismic properties calculated based on the composition and crystal preferred orientation of the xenoliths to seismological data in the Atlantic (Gaherty et al., 2004; Harmon et al., 2018; Kendall et al., 2017; Silveira \& Stutzmann, 2002), aiming to elucidate the physical and chemical processes that shaped the lithosphere mantle of a low-spreading rate oceanic plate, which had a significant strike-slip component of deformation during the early stages of evolution and was later affected by a hot spot-type volcanism, which formed the FN islands.

\section{Geological Background}

The Fernando de Noronha (FN) archipelago is located in the west equatorial Atlantic just south of the Chain fracture zone, approximately $350 \mathrm{~km}$ away from the northeast Brazil coastline (Figure 1). The islands formed onto 100-105-Ma-old oceanic crust (early-late Cretaceous boundary) based on magnetic anomaly data (Nemčok et al., 2013, and references therein).

The archipelago forms the easternmost tip of an E-W volcanic alignment that extends from the Ceara coast in northeast Brazil (the Mecejana volcanic field; Figure 1). The few age data available for this volcanic alignment show no regular progression, but eruption ages tend to be younger eastward. The Mecejana volcanics on the Brazilian coast yield K-Ar ages between 26 and 44 Ma (Mizusaki et al., 2002), whereas volcanism in 
Fernando de Noronha has whole-rock, feldspar, nepheline, and kaersutite Ar-Ar ages between 12.5 and $6 \mathrm{Ma}$ (Perlingeiro et al., 2013).

The volcanism in Fernando de Noronha is characterized by multiple eruption episodes. Ar-Ar dating highlights three groups of ages for the outcropping lavas (Perlingeiro et al., 2013). The Remédios formation, which forms the bulk of the island, yields older ages between $12.5 \pm 0.1$ and $9.4 \pm 0.2 \mathrm{Ma}$. The basanite and alkaline basalt lava flows of the São José formation, which host the mantle xenoliths studied here, have ages of $9.5 \pm 0.4$ and $9.0 \pm 0.1 \mathrm{Ma}$. The nephelinites of the Quixaba formation are younger; they erupted between $6.2 \pm 0.1$ and $1.3 \pm 0.1$ Ma.

Previous studies on FN mantle xenoliths coupled petrographic and geochemical analyses aiming to characterize the effect of the Fernando de Noronha mantle plume on the lithospheric mantle (Kogarko et al., 2001; Rivalenti et al., 2000). These studies revealed two textural groups: a protogranular or granoblastic group, which predominates, and a minor porphyroclastic group. The two groups show similar equilibrium temperatures, in the range $980-1150{ }^{\circ} \mathrm{C}$ (Rivalenti et al., 2000). Both studies proposed that the lithospheric mantle beneath Fernando de Noronha has been subjected to variable degrees of metasomatism. Yet the two studies infer different metasomatic agents: carbonated melts for Kogarko et al. (2001) or melts with an EMII-type isotopic signature, similar to the Remedios lavas for Rivalenti et al. (2000). This earlier study also presented evidence for reactive melt flow leading to changes in the mode (clinopyroxene or olivine enrichment at the expenses of orthopyroxene) and marked enrichment in incompatible elements, which is more developed in porphyroclastic peridotites.

\section{Methods}

\subsection{Sampling}

The studied xenoliths were collected from basanites from the São José formation in the São José islet, in the north of the main island of Fernando de Noronha $\left(3^{\circ} 49^{\prime} 39^{\prime \prime} \mathrm{S}, 32^{\circ} 24^{\prime} 05^{\prime \prime} \mathrm{W}\right)$. We have analyzed 21 new xenoliths and 3 previously studied by Rivalenti et al. (2000). Most xenoliths are small (on average $3 \mathrm{~cm}$ of diameter), except 3 , which have $\sim 10 \mathrm{~cm}$ in diameter, but they are very fresh and devoid of evidence of major interaction with the host lava. Petrostructural analyses were performed on all samples. Mineral compositions were analyzed in 13 samples, selected as to ensure that all microstructural types were represented.

\subsection{Electron-Backscattered Diffraction Data Acquisition and Treatment}

Crystallographic preferred orientations (CPOs) of olivine, pyroxenes, and spinel were measured by indexing of electron-backscattered diffraction patterns in the SEM-EBSD facility at Geosciences Montpellier, France. All thin sections were carefully polished before measurements. Data acquisition was performed using a JEOL JSM 5600 scanning electron microscope with 17-kV acceleration voltage and 24-mm working distance. We did electron-backscattered diffraction (EBSD) mapping over the entire thin section (areas $\geq 2 \times 3 \mathrm{~cm}^{2}$ ) with step sizes between 8 and $35 \mu \mathrm{m}$, depending on grain size. Indexation rates ranged between $84 \%$ and 97\%. During postacquisition data treatment, we eliminated inaccurate indexing points ( $\mathrm{MAD}>1.3^{\circ}$ and wild spikes, that is, single-pixel results inconsistent with the surrounding data), corrected for rare olivine pseudosymmetry misindexing, and filled up nonindexed pixels with at least six coherent neighboring measurements with the average of the neighbors' orientations.

The CPO data analyses, that is, the calculation of the orientation distribution functions and of the misorientations, the computation of the strength and symmetry of the olivine $\mathrm{CPO}$, the plotting of pole figures, and the quantification of the microstructure (grain size, shape, and orientation), were performed using the MTEX toolbox in MATLAB (http://mtex-toolbox.github.io/; Hielscher \& Schaeben, 2008; Bachmann et al., 2010; Bachmann et al., 2011). The orientation distribution functions were calculated using a "de la Vallée Poussin" kernel function with a half-width of $10^{\circ}$. The CPO is presented as one crystallographic orientation per pixel in pole figures.

Thin sections were cut in random orientations, because most samples were small and the foliation and lineation were difficult to identify in most hand samples. However, all samples have well-defined olivine CPO, with clear [100] and [010] alignments, which are always stronger than the [001] ones. Numerical models of olivine CPO evolution show that such olivine CPO forms in response to dominant activation of the [100](010) slip system (Tommasi et al., 2000). Thus, to facilitate comparison between samples, we rotated 
the CPO of each sample to a similar orientation, in which the [100] axis of olivine is parallel to the E-W direction and the [010] axis of olivine is parallel to the N-S direction of the pole figure.

The strength of the CPO was quantified using the dimensionless J index (Bunge, 1982). The J index for a random CPO is 1; it can reach up to 20 in natural peridotites, with a peak at 3-5 (Tommasi \& Vauchez, 2015). We use the dimensionless BA index (Mainprice et al., 2014) to describe the olivine CPO symmetry. This index allows classifying the olivine CPO into three types: (i) fiber-[010], defined by a [010] point concentration and girdle distributions of [100] and [001] (BA-index <0.35); (ii) orthorhombic, characterized by orthogonal point concentrations of [100], [010], and [001] (0.35< BA index <0.65); and (iii) fiber-[100], defined by a point concentration of [010] and girdle distributions of [010] and [001] (BA Index $>0.65$ ).

We used the grain detection method in MTEX (Bachmann et al., 2011) to identify the grains in the map. Grain boundaries were defined by misorientation angles between adjacent pixels higher than $15^{\circ}$. Grains composed by less than 10 pixels were not considered in the microstructural analyses, since grain shapes and intragranular misorientations are poorly defined for grains described by few pixels. The misorientation of each pixel relative to the mean orientation of the grain (M2M) and the grain orientation spread (GOS) were calculated using built-in MTEX functions to quantify the intracrystalline orientation gradients, which are a proxy of the dislocation density. Both should decrease during dynamic and static recrystallization due to nucleation and grain boundary migration (Rollet et al., 2017). Area-weighted M2M averages over the entire EBSD map are thus used to compare the degree of recrystallization between different samples. The sinuosity of grain shapes is quantified by the shape factor, which is the ratio between the actual perimeter of the grain and the perimeter of a circle with the same area. The shape factor should decrease in response to recrystallization, in particular during annealing, when decrease in grain boundary energy becomes the main driving force for grain boundary migration (Rollet et al., 2017).

\subsection{Mineral Compositions and $\boldsymbol{P}$ - $\boldsymbol{T}$ Calculations}

Mineral compositions of olivine (ol), orthopyroxene (opx), clinopyroxene (cpx), and spinel were measured on a Cameca SX100 electron microprobe at the University of Montpellier, France. The experiments were carried out using a 20-kV accelerating voltage and a 10-nA current. For each sample, we analyzed rim and core compositions in three to four grains of olivine, orthopyroxene, clinopyroxene, and spinel.

Following Nimis and Grutter (2010), we used the two-pyroxene geothermometer (Taylor, 1998) and the Cain-opx geothermometer (Brey \& Kohler, 1990; revised by Nimis \& Grutter, 2010) to calculate equilibrium temperatures. Average rim and core equilibrium temperatures were calculated by averaging the temperatures calculated using three to four rim or core compositions of individual opx grains or opx-cpx pairs for each sample. Since no reliable barometers are available for spinel-facies peridotites, we chose $1.5 \mathrm{GPa}$ ( 46-km depth) as the pressure to calculate the two thermometers. Uncertainty in the assumed pressure produces $\sim 10^{\circ} \mathrm{C}$ variation per $0.5 \mathrm{GPa}(\sim 11 \mathrm{~km})$.

\subsection{Seismic Properties}

Seismic properties were computed using the MTEX toolbox (Mainprice et al., 2011). The seismic properties of each sample were calculated using a Voigt-Reuss-Hill averaging, based on the CPOs and modal content of olivine, orthopyroxene, and clinopyroxene derived from the EBSD maps and on the single crystal elastic constant tensors of olivine, orthopyroxene, and clinopyroxene and their temperature and pressure derivatives (Abramson et al., 1997; Anderson et al., 1992; Chai et al., 1997; Isaak et al., 2006; Jackson et al., 2007; Sang \& Bass, 2014). Average seismic properties for the lithospheric mantle beneath Fernando de Noronha were estimated by averaging the elastic constant tensors of all samples. For this, the CPO data were rotated into a common reference frame in which the olivine [100] and [010] maxima of all samples are parallel. In aligning the CPO data, priority was arbitrarily given for aligning the [010] axes in the N-S direction, leading to some dispersion in the alignment of the [100] axes. Although it results from an arbitrary choice, the nonperfect alignment of the CPO data mimics the variations in the orientation of the lineation observed when mapping flow structures in peridotite massifs at the hundreds of meters to kilometers scale even when the entire massif records a single large-scale deformation event (e.g., Frets et al., 2014). This average is therefore a realistic estimate of the maximum seismic anisotropy that could be produced at scales larger than the kilometer in the lithospheric mantle beneath Fernando de Noronha. 


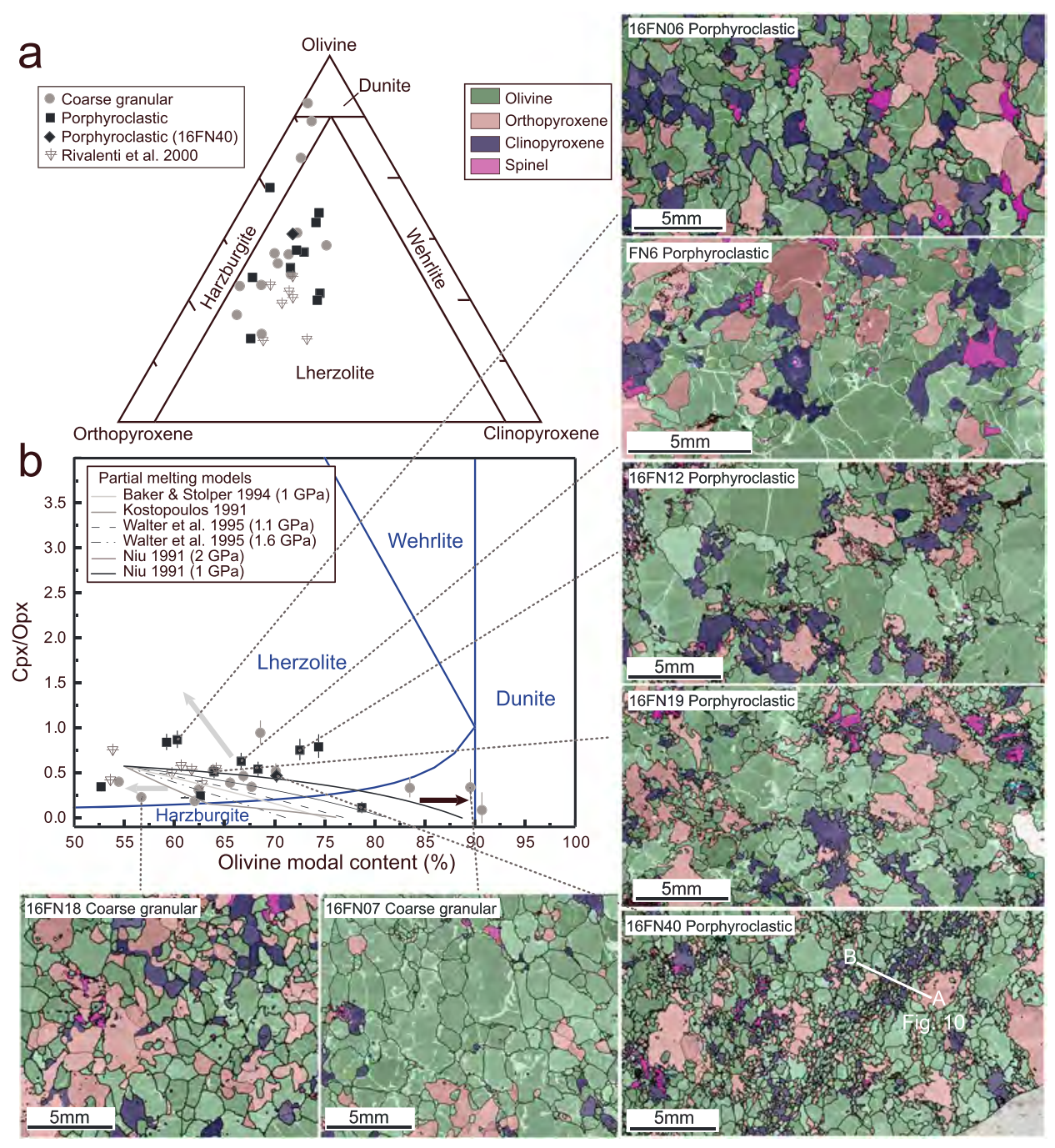

Figure 2. Modal compositions and EBSD phase maps. (a) Olivine-clinopyroxene-orthopyroxene ternary diagram comparing with the modal compositions from Rivalenti et al. (2000). (b) Clinopyroxene/orthopyroxene versus olivine diagram. Modal composition evolutions predicted by isobaric partial melting models with an initial fertile modal composition of 55\% ol, 28.5\% opx, and 16.5\% cpx are plotted for comparison (Baker \& Stolper, 1994; Kostopoulos, 1991; Niu, 1997; Walter, 1999; Walter et al., 1995). Gray arrows represent cpx and opx crystallization at the expense of ol (refertilization reactions); black arrow represents ol crystallization at the expense of cpx and opx (dunitization reactions). EBSD phase maps illustrate the spatial distribution of the mineral phases and microstructures in representative samples. White dashed line A-B in 16FN40 EBSD map marks the location of the chemical variation profile across the recrystallized band presented in Fig. 10.

\section{Results}

\subsection{Modal Compositions}

Modal compositions were defined based on the area fraction of each mineral in the EBSD maps (Figure 2 and Table 1). All xenoliths are spinel-facies peridotites. Most are lherzolites with olivine contents ranging from 50 to $75 \%$ and clinopyroxene to orthopyroxene ratios of 0.2 to 1 . Three are harzburgites and one is a dunite. Previous sampling of mantle xenoliths in Fernando de Noronha by Rivalenti et al. (2000) also displayed predominance of fertile lherzolites (Figures $2 \mathrm{a}$ and $2 \mathrm{~b}$ ); the similarity between the two samplings suggests that it is a characteristic feature of the FN xenoliths.

Comparison of the observed modal compositions to those predicted by different partial melting models (Figure 2b) indicates that many FN xenoliths have modal compositions inconsistent with a simple partial melting evolution. At least seven lherzolites show too high cpx/opx ratios relative to their olivine modal 
Table 1

Rock Types, Microstructures, Modal Compositions, Thermometry, and Bulk-Rock Mg\#

\begin{tabular}{|c|c|c|c|c|c|c|c|c|c|c|c|c|c|c|c|c|}
\hline \multirow[b]{3}{*}{ Sample } & \multirow{3}{*}{$\begin{array}{l}\text { Rock } \\
\text { Type }\end{array}$} & \multirow{3}{*}{\multicolumn{2}{|c|}{$\begin{array}{l}\text { Microstructure } \\
\text { rex Fraction (\%) }\end{array}$}} & & & & & \multicolumn{8}{|c|}{ Thermometry ${ }^{\mathrm{a}}\left({ }^{\circ} \mathrm{C}\right)$} & \multirow{3}{*}{$\begin{array}{c}\begin{array}{c}\text { Bulk } \\
\text { Rock }\end{array} \\
\text { Mg\# }\end{array}$} \\
\hline & & & & \multicolumn{4}{|c|}{ Modal Composition (\%) } & \multicolumn{4}{|c|}{ Two-pyroxene } & \multicolumn{4}{|c|}{ Ca-in-opx } & \\
\hline & & & & $\mathrm{Ol}$ & Opx & Cpx & $\mathrm{Sp}$ & Rim & $\mathrm{Sd}$ & Core & Sd & Rim & $\mathrm{Sd}$ & Core & $\mathrm{Sd}$ & \\
\hline 16FN05 & $\mathrm{Du}$ & c & & 91 & 7 & 6 & 2 & 1070 & 66 & 978 & 11 & 1009 & 3 & 1008 & 2 & 89.9 \\
\hline 16FN07 & $\mathrm{Hz}$ & c & & 90 & 8 & 3 & $<1$ & 970 & 25 & 963 & 22 & 1008 & 0 & 1005 & 5 & 89.7 \\
\hline 16FN35 & $\mathrm{Hz}$ & c & & 83 & 12 & 4 & $<1$ & 979 & 25 & 979 & 8 & 1020 & 4 & 1018 & 3 & 90.0 \\
\hline 16FN01 & $\mathrm{Lz}$ & c & & 64 & 23 & 12 & 1 & 840 & 22 & 863 & 28 & 908 & 6 & 937 & 8 & 89.0 \\
\hline 16FN16 & $\mathrm{Lz}$ & c & & 66 & 24 & 9 & 1 & 965 & 18 & 977 & 13 & 1004 & 4 & 1004 & 4 & 90.3 \\
\hline 16FN18 & $\mathrm{Lz}$ & c & & 57 & 34 & 8 & 2 & 948 & 5 & 949 & 16 & 1010 & 49 & 987 & 6 & 89.9 \\
\hline $16 \mathrm{FN} 21$ & $\mathrm{Lz}$ & c & & 55 & 32 & 13 & $<1$ & & & & & & & & & \\
\hline 16FN29 & $\mathrm{Lz}$ & c & & 69 & 16 & 14.81 & 1 & 864 & 52 & 868 & 21 & 889 & 28 & 911 & 17 & 89.6 \\
\hline 16FN32 & $\mathrm{Lz}$ & c & & 68 & 24 & 8 & 0.32 & 997 & 14 & 989 & 11 & 1020 & 7 & 1019 & 3 & 89.4 \\
\hline $16 \mathrm{FN} 33$ & $\mathrm{Lz}$ & C & & 62 & 28 & 9 & $<1$ & & & & & & & & & \\
\hline 16FN38 & $\mathrm{Lz}$ & c & & 67 & 22 & 10 & 1 & & & & & & & & & \\
\hline 16FN50 & $\mathrm{Lz}$ & C & & 70 & 19 & 10 & 2 & & & & & & & & & \\
\hline FN50 & $\mathrm{Lz}$ & $\mathrm{C}$ & & 62 & 31 & 6 & 1 & & & 992 & & & & 914 & & 90.0 \\
\hline 16FN02 & $\mathrm{Lz}$ & Porph & 8 & 63 & 28 & 7 & 2 & & & & & & & & & \\
\hline 16FN06 & $\mathrm{Lz}$ & Porph & 15 & 60 & 20 & 18 & 2 & & & & & & & & & \\
\hline 16FN09 & $\mathrm{Lz}$ & Porph & 13 & 53 & 34 & 12 & 2 & & & & & & & & & \\
\hline 16FN12 & $\mathrm{Lz}$ & Porph & 14 & 73 & 15 & 12 & 1 & 886 & 12 & 898 & 10 & 926 & 6 & 933 & 19 & 89.9 \\
\hline 16FN19 & $\mathrm{Lz}$ & Porph & 26 & 64 & 22 & 11 & 3 & 1002 & 116 & 993 & 95 & 960 & 9 & 965 & 8 & 88.3 \\
\hline 16FN30 & $\mathrm{Lz}$ & Porph & 18 & 59 & 21 & 18 & 2 & 815 & 22 & 849 & 23 & 895 & 5 & 899 & 6 & 89.7 \\
\hline 16FN37 & $\mathrm{Lz}$ & Porph & 12 & 74 & 14 & 11 & $<1$ & 1000 & 19 & 993 & 12 & 1009 & 9 & 1010 & 5 & 89.4 \\
\hline 16FN48 & $\mathrm{Lz}$ & Porph & 13 & 68 & 21 & 11 & $<1$ & & & & & & & & & \\
\hline $\mathrm{FN}^{\mathrm{c}}$ & $\mathrm{Lz}$ & Porph & 15 & 67 & 19 & 12 & 2 & & & 948 & & & & 1030 & & 90.8 \\
\hline FN93-55 & $\mathrm{Hz}$ & Porph & 14 & 79 & 19 & 2 & $<1$ & & & 959 & & & & 976 & & 89.5 \\
\hline $16 \mathrm{FN} 40$ & $\mathrm{Lz}$ & Porph & 46 & 70 & 19 & 9 & 1 & 926 & 6 & 957 & 34 & 966 & 3 & 972 & 16 & 89.7 \\
\hline
\end{tabular}

Note. Hz: harzburgite, Lz: lherzolite, Du: dunite, CG: coarse-granular; Porph: porphyroclastic.

a Two-pyroxene thermometer (TTA98; Taylor, 1998), Ca-in-opx thermometer (Ca-in-opx; Brey \& Kohler, 1990; revised by Nimis \& Grutter, 2010). ${ }^{\mathrm{b}}$ Estimated from average chemical composition and modal contents (area.\%) of each mineral. ' ${ }^{c}$ Samples from Rivalenti et al. (2000).

content. Three lherzolites with low olivine modal content $(<60 \%)$ display too low cpx/opx ratios. Two harzburgites and the dunite show higher cpx/opx ratios than those predicted by the partial melting models for the same olivine modal content. These modal compositions may be explained by reactive melt percolation leading to either crystallization of orthopyroxene or clinopyroxene at the expense of olivine (refertilization reactions; represented by the gray arrows in Figure 2), or crystallization of olivine at the expense of pyroxenes (dunitization reactions; black arrow in Figure 2). Petrographic evidence for such reactions in the Fernando de Noronha peridotites encompasses (i) sinuous olivine-pyroxene boundaries and (ii) cusp-like shapes of pyroxenes when in contact with two olivine grains (cf. EBSD phase maps in Figure 2).

\subsection{Microstructures}

All studied xenoliths are coarse-grained. Mean 2-D grain sizes (diameter of the equivalent sphere with the same area as the grain in EBSD map, weighted by the grain area) of olivine and orthopyroxene range between 1 and $3.5 \mathrm{~mm}$, except for the strongly recrystallized lherzolite 16FN40, which has smaller average olivine grain sizes (Figure 3). Clinopyroxene has smaller mean grain sizes between 0.4 and $1.5 \mathrm{~mm}$. Average apparent (2-D) aspect ratios (the ratio between the length and width of the equivalent ellipsoid on the plane of the thin section, weighted by the grain area) of the three phases have a similar range between 1.5 and 1.9, except for orthopyroxene in lherzolites 16FN33 and FN50, which have average apparent aspect ratios of 2.03 and 2.15 (Table 2 and Figure 3). Despite the slight elongation of the grains, many samples show no clear shape preferred orientation defining a foliation or a lineation (Figures 2 and 4).

Previous studies (Rivalenti et al., 2000) tried to correlate the microstructures with the chemical compositions and equilibrium temperatures. They divided FN xenoliths into a protogranular and a porphyroclastic group. In the present study, we combined optical observations (Figures 4 and 5) with quantitative data 


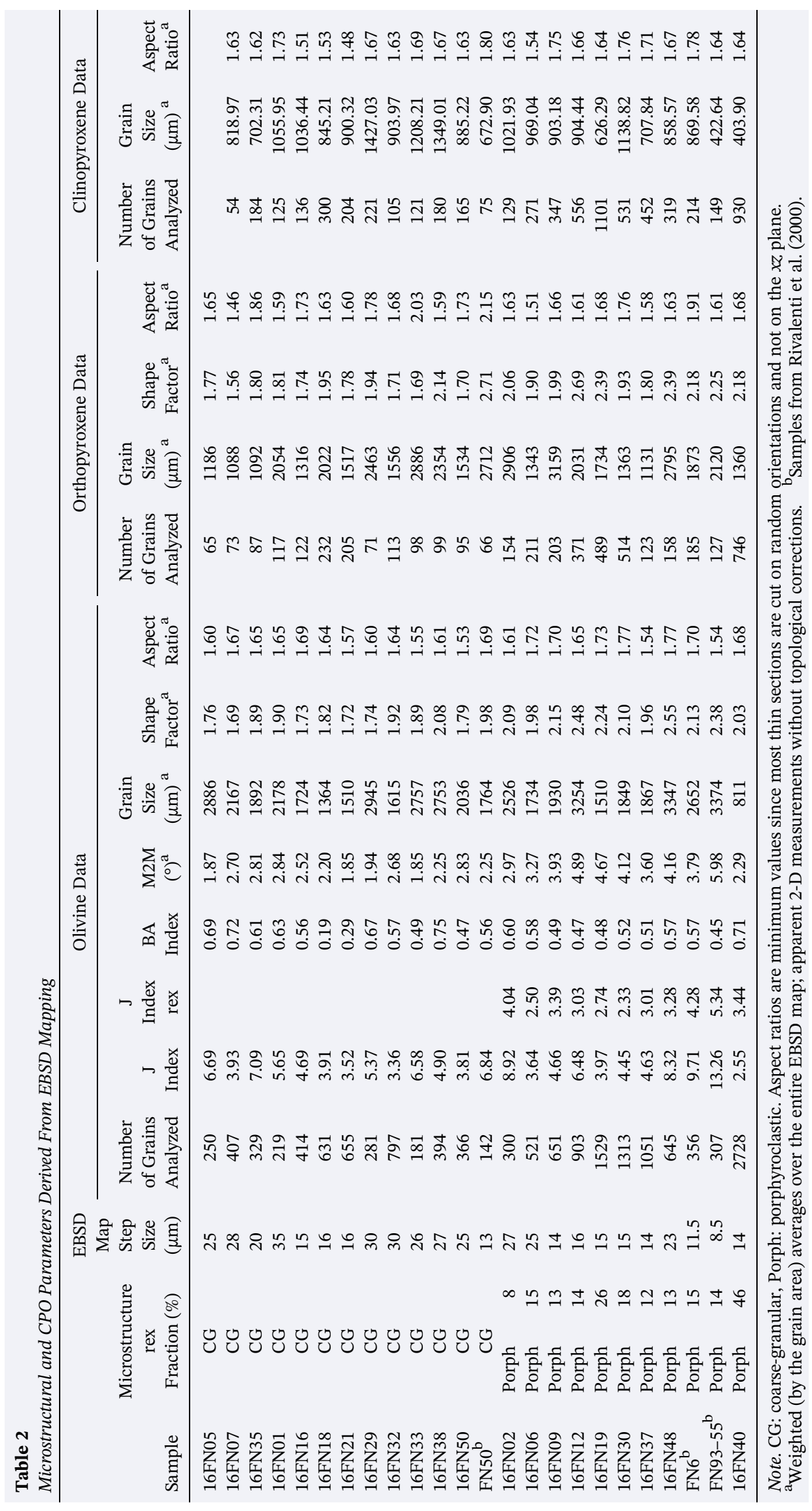




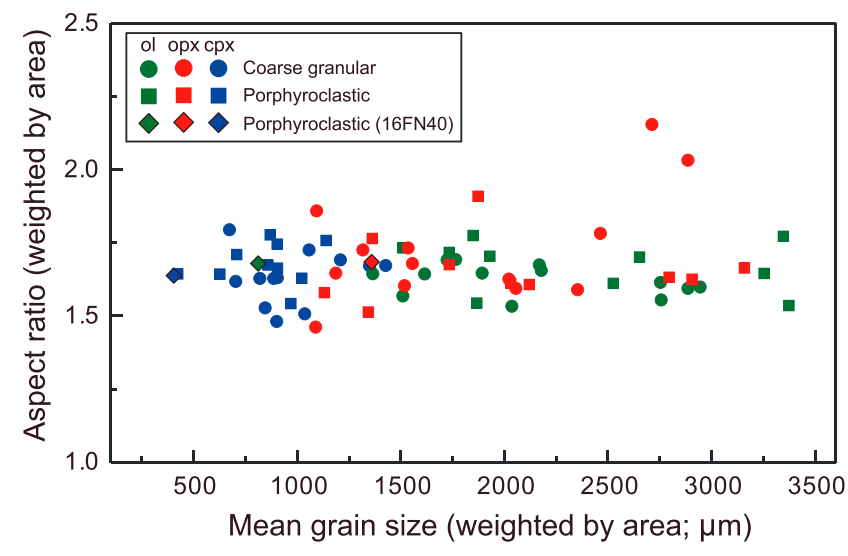

Figure 3. Mean grain size (2-D) versus aspect ratio of olivine (ol), orthopyroxene (opx), and clinopyroxene (cpx) for all analyzed peridotites; both are apparent (2-D) values derived from EBSD data weighted by grain area. Aspect ratios are minimum values, since many thin sections were cut in random orientations and not on the plane normal to the foliation and parallel to the lineation. derived from EBSD mapping (Table 2 and Figure 6) to analyze the microstructures of the xenoliths. This analysis reveals a continuous variation between two microstructural end-members: coarse-granular and coarse-porphyroclastic. Although the variation between the two microstructures is continuous, the quantitative analysis of the olivine intracrystalline misorientations and of the shapes of olivine and ortho-pyroxene (Figure 6) allows separating the samples into two groups.

Coarse-granular peridotites correspond roughly to the protogranular textures of Rivalenti et al. (2000). However, we choose not to use the term protogranular, because the later has, in its original definition (Mercier \& Nicolas, 1975), a connotation of undeformed, which is not applicable to the samples studied here, as it will be shown by the analysis of the crystal preferred orientations. Coarse-granular peridotites have equigranular microstructures (Figures $4 \mathrm{a}$ and $4 \mathrm{~b}$ ). Olivine shows dominantly polygonal grain shapes (Figures 2 [phase maps], 4a, and 4b), with straight to slightly curvilinear grain boundaries, often forming $120^{\circ}$ triple junctions (Figure 5b), which indicate effective annealing. Pyroxenes have more irregular grain shapes (Figures 2 and $4 \mathrm{~b}$ ), but straight grain boundaries and $120^{\circ}$ triple junctions are also locally observed (Figure $4 \mathrm{a}$ and arrows in Figure $5 \mathrm{~b}$ ) These grain shapes are associated with low shape factors (Figure 6), which range between 1.6 and 2.1 for olivine and 1.5 and 2.3 for orthopyroxene. A single outlier (FN50) has an orthopyroxene shape factor of 2.7, which may result from the low number of orthopyroxene grains analyzed due to the small size
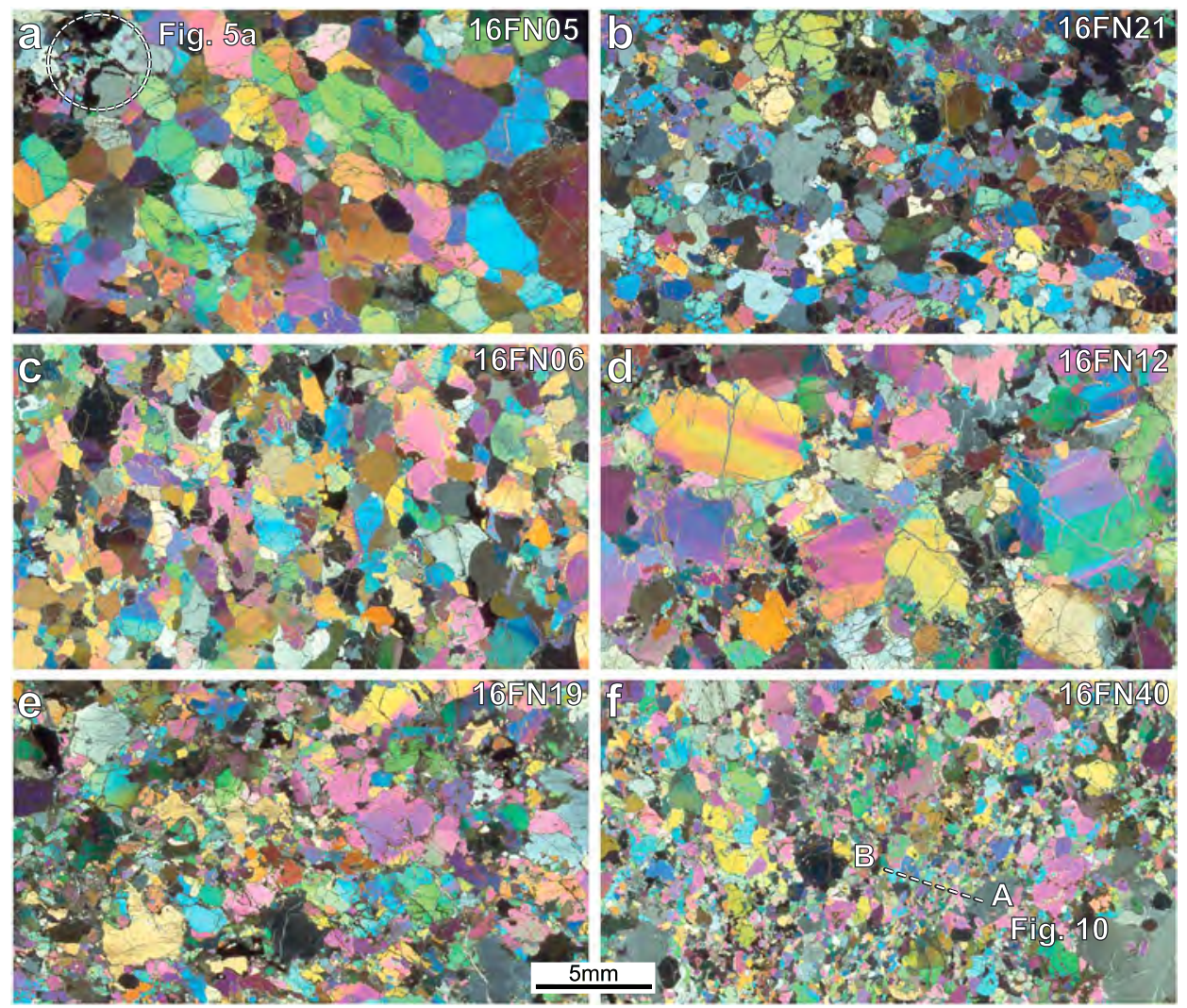

Figure 4. Thin-section-scale photomicrographs in cross-polarized light of typical microstructures. (a, b) Coarse granular peridotites; white circle in (a) marks the pyroxene-spinel aggregate shown in Figure 5a. (c-e) Porphyroclastic peridotites showing increasing degrees of recrystallization. (f) Strongly recrystallized porphyroclastic lherzolite 16FN40; dashed line A-B locates the profile along which the variations in mineral chemistry across the recrystallized band in $16 \mathrm{FN} 40$ were analyzed (Figure 10). The scale bar is the same for all photomicrographs. 

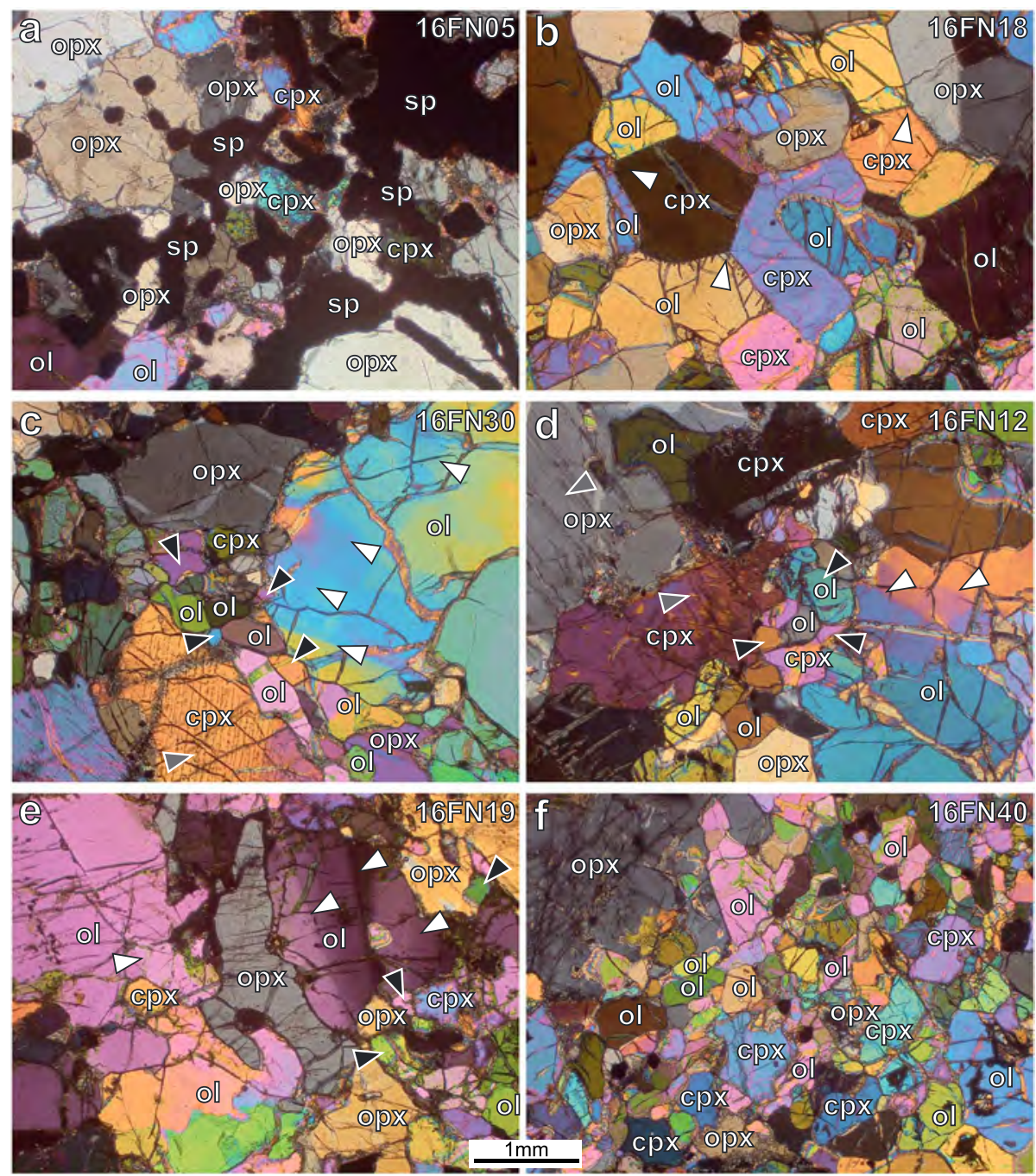

Figure 5. Photomicrographs in cross-polarized light illustrating characteristic features of both microstructures. (a) Opxcpx-sp aggregate in coarse granular harzburgite 16FN05. (b) Coarse granular lherzolite 16FN18 exhibiting straight grain boundaries with $120^{\circ}$ junctions even between olivine and pyroxenes (white arrows). (c-e) Porphyroclastic lherzolites 16FN30, 16FN12, and 16FN19 showing olivine porphyroclasts with undulose extinction and subgrain boundaries (white arrows) as well as variable amounts of polygonal, strain-free olivine neoblasts (black arrows), pyroxenes with exsolutions (gray arrows in (c) and (d)), and sinuous olivine-pyroxene boundaries implying melt-rock reaction. (f) Strongly recrystallized porphyroclastic lherzolite $16 \mathrm{FN} 40$ showing the assemblage of strain-free ol $+\mathrm{cpx} \pm \mathrm{opx}$ neoblasts that characterize the recrystallized domains, as well as an opx porphyroclast (top left) with very sinuous grain boundaries. Scale bar is the same for all photomicrographs.

of the sample. Olivine grains display weak intracrystalline misorientations, except in harzburgites 16FN07 and 16FN35, which have olivines with undulose extinction. The weak intragranular misorientation is consistent with the low average M2M values for olivine of coarse-granular peridotites, from $1.85^{\circ}$ to $2.84^{\circ}$ (Figure 6a). Orthopyroxene and clinopyroxene occur most often dispersed in the thin sections, but some coarse-granular peridotites (16FN05, 16FN18, 16FN29, and 16FN33) show opx-cpx-sp aggregates (Figures 4a and 5a) that might represent former garnets. Orthopyroxene may contain olivine inclusions. Undulose extinction or kinks are rare. Spinel grains have smaller grain sizes than the other major phases and irregular grain shapes.

Porphyroclastic peridotites (Figures 4c-4e) are characterized by more sinuous grain boundaries of both olivine and pyroxenes (higher shape factors up to 2.55 and 2.69 for olivine and orthopyroxene, respectively; Figure 6) and higher average intragranular misorientations in olivine (average $\mathrm{M} 2 \mathrm{M} \geq 3^{\circ}$; Figure 6). Some porphyroclastic peridotites show a bimodal distribution of olivine grain sizes and shapes, characterized by 

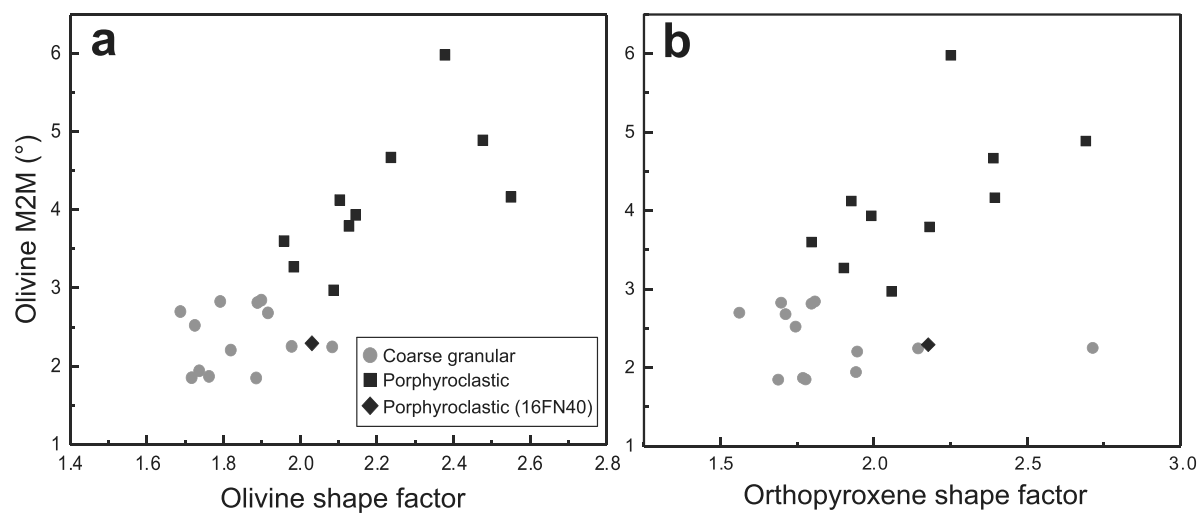

Figure 6. Microstructural parameters derived from EBSD data. (a) Mean olivine shape factor versus mean intragranular misorientation (M2M; misorientation relative to the mean orientation of the grain in degrees). (b) Orthopyroxene shape factor versus olivine M2M. All values are area-weighted averages over the entire EBSD map. The shape factor is the ratio between the actual perimeter of the grain and the perimeter of a circle with the same area as the grain.

co-existence of coarse olivine crystals $(>1 \mathrm{~mm}$ ) with serrated grain boundaries, undulose extinction, and common subgrain boundaries (porphyroclasts) and fine grains with more polygonal shapes and low intracrystalline misorientations (recrystallized grains; Figures $4 \mathrm{c}-4 \mathrm{f}$ and $5 \mathrm{c}-5 \mathrm{f}$ ). The proportion of fine grains attains $46 \%$ in lherzolite 16FN40 (Figures $4 \mathrm{f}$ and 5f), resulting in low average M2M and shape factors for this sample (Figure 6). However, most porphyroclastic peridotites show low volumes of recrystallized olivine (Figures $4 \mathrm{c}-4 \mathrm{e}$ and Table 2). Fine-grained olivine is often accompanied by local enrichment in fine-grained orthopyroxene and clinopyroxene (Figures 2 [phase maps] and $5 \mathrm{~d}-5 \mathrm{f}$ ). It is noteworthy that the fine-grained domains are not arranged preferentially parallel to the elongation of the coarse olivine grains, marking a foliation. They either form irregular patches or vein-like structures (Figures 4d-4f). Olivine porphyroclasts are often slightly elongated, marking a weak foliation (Figures 4c and $4 \mathrm{~d}$ ). They display undulose extinction and well-developed subgrains (white arrows in Figures 5c-5e). Coarse orthopyroxene and clinopyroxene crystals have very irregular shapes and pyroxene-olivine grain boundaries are highly sinuous, with pyroxenes often displaying cusp-like shapes when in contact with two olivine grains (Figures 2 [phase maps], 4c-4f, and 5c-5f). Orthopyroxene porphyroclasts show weak undulose extinction. Exsolutions in pyroxenes are observed in several samples (gray arrows in Figures 5c and 5d). Small pyroxene crystals have interstitial shapes (Figures 5d-5f). Spinel is present as irregularly shaped grains usually associated with orthopyroxene and/or clinopyroxene (cf. EBSD phase maps in Figure 2).

\subsection{Crystallographic Preferred Orientations}

Crystallographic preferred orientations (CPOs) of olivine, orthopyroxene, and clinopyroxene for all studied xenoliths are shown in Figure 7. The relationship between CPO and shape-preferred orientation could not be analyzed in many samples, because the foliation and lineation were not identified in hand samples or thin sections. However, in most samples, the olivine CPO is characterized by orthorhombic patterns with stronger maxima of [100] and [010] relatively to [001]. This qualitative observation is corroborated by the analysis of the olivine CPO strength (J index) versus CPO symmetry (BA index) diagram, which shows that moderated or strong CPOs with orthorhombic to fiber-[100] patterns predominate (Figure 8; data presented in Table 2). Porphyroclastic peridotites display dominantly orthorhombic patterns, but of highly variable intensity ( $\mathrm{J}$ indexes between 2.6 and 13.3 , with the strongly recrystallized lherzolite 11FN40 displaying the lowest value and coarse porphyroclastic lherzolites with very low volume fractions of recrystallized grains, the higher values, $>8$ ). Coarse-granular peridotites show more homogeneous olivine CPO intensities (J indexes between 3.4 and 7.1), but more variable CPO symmetry. Orthorhombic patterns predominate, but some coarse granular samples show a tendency toward a fiber-[010] pattern (16FN18, 16FN21) and others toward a fiber-[100] pattern (16FN05, 16FN07, 16FN29, 16FN38).

In porphyroclastic peridotites, separate analysis of the CPO of recrystallized olivine crystals (discriminated based on their intracrystalline misorientation, grain orientation spread $<2.5^{\circ}$, and grain sizes $<350 \mu \mathrm{m}$ ) 


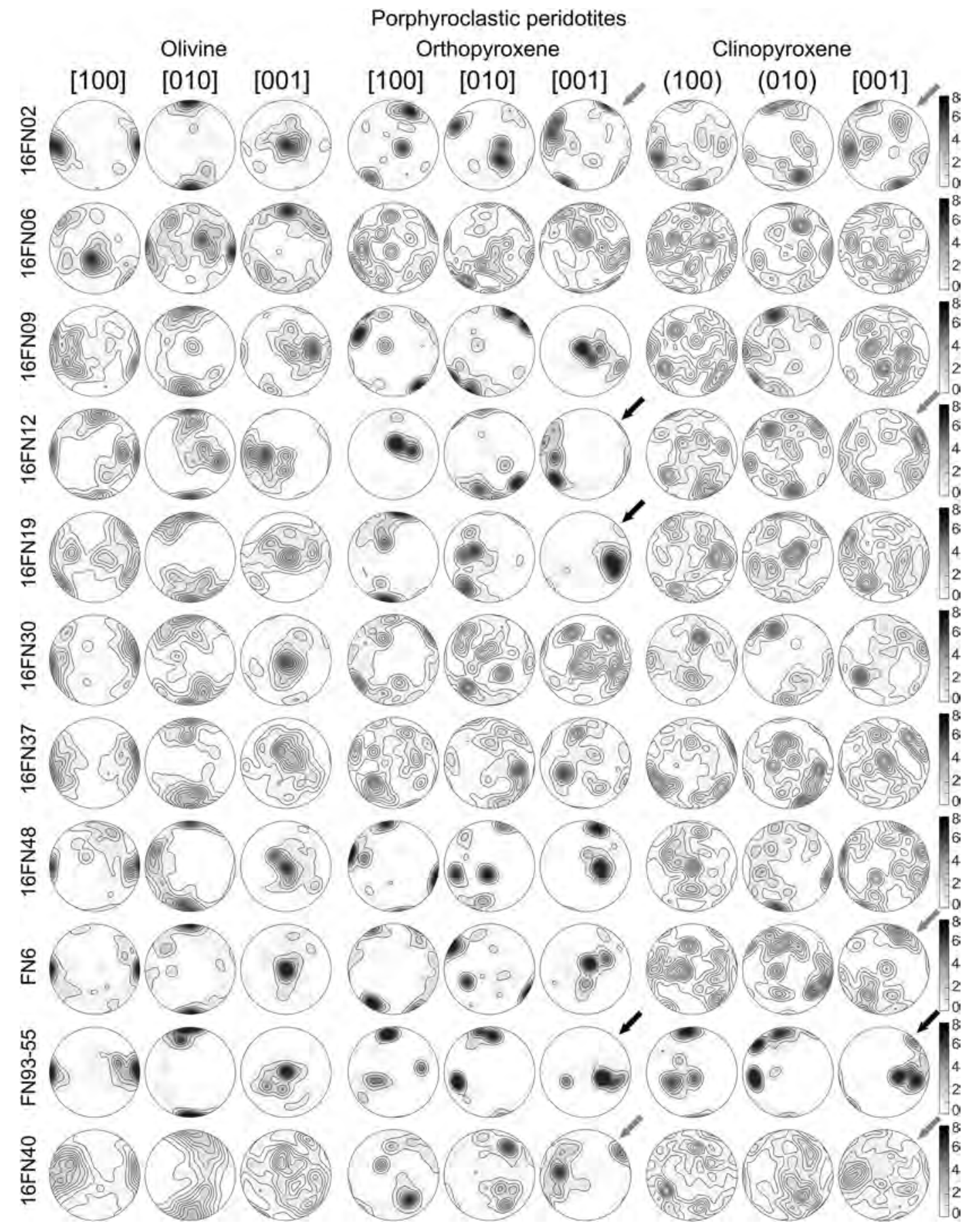

Figure 7. Crystal preferred orientations (CPO) of olivine, orthopyroxene, and clinopyroxene for all samples. Lower hemisphere stereographic projections. All pole figures are presented using the same color scale, which ranges between 0 and 8 multiples of a uniform distribution. Contours at 1 multiple of a uniform distribution interval. Black arrows indicate pyroxene CPOs correlated with the olivine ones and gray arrows mark those that are partially correlated (see text for definition of the correlation criterion). Very strong maxima in pyroxenes CPO for some samples result from the presence of a few coarse grains, in the analyzed area, these $\mathrm{CPO}$ are, by consequence, not statistically representative When $<100$ grains were measured, data are presented as points, instead of density-contoured.

shows that recrystallized grains have in general more dispersed CPO (gray crosses in Figure 8) than the bulk rock. The exception is the strongly recrystallized lherzolite $16 \mathrm{FN} 40$, in which $46 \%$ of the mapped area is composed by recrystallized grains and, by consequence, has a weak bulk CPO. However, although the bulk and recrystallized grains CPO strength is similar, the recrystallized grains show a 


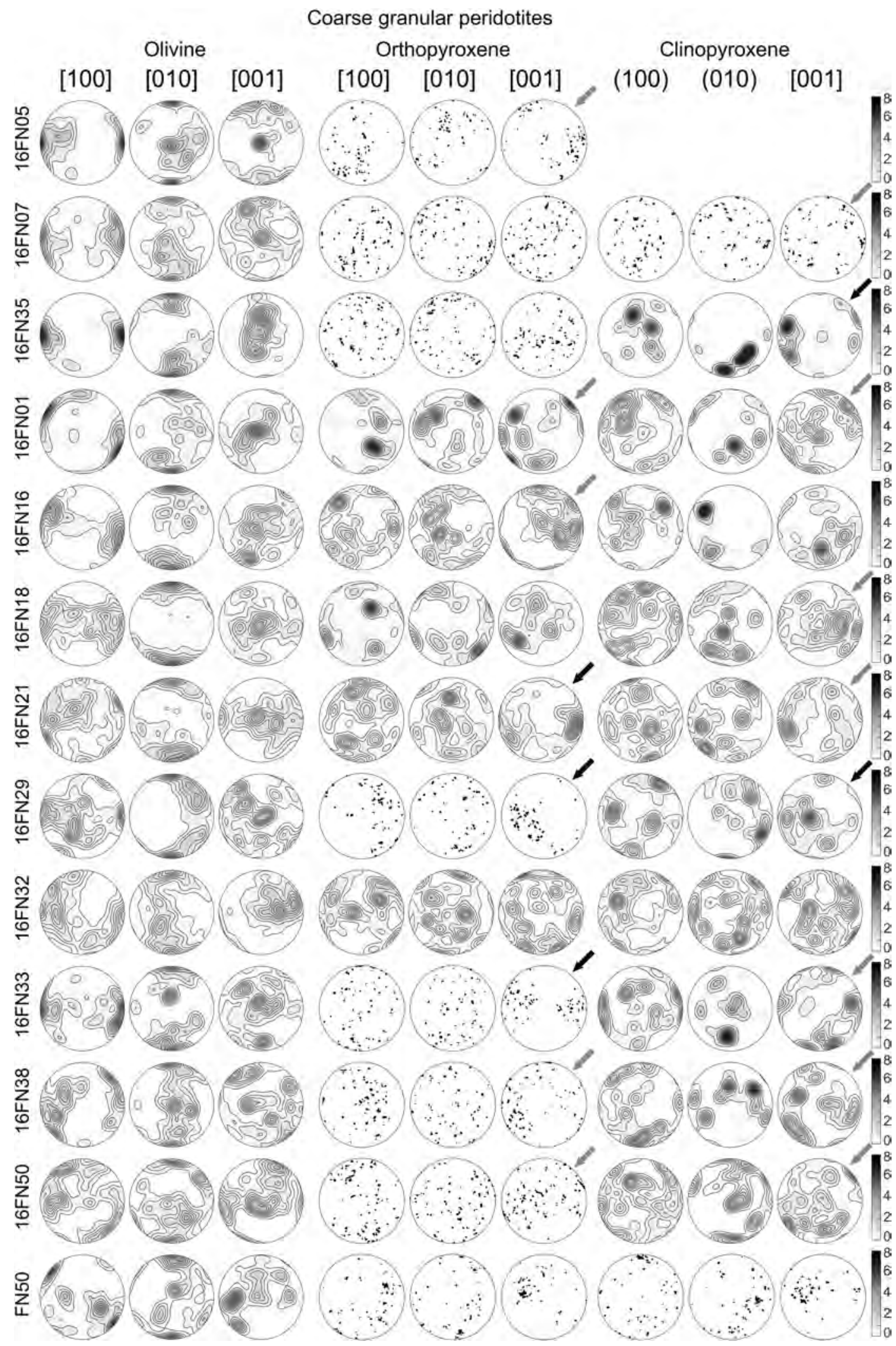

Figure 7. (continued) 


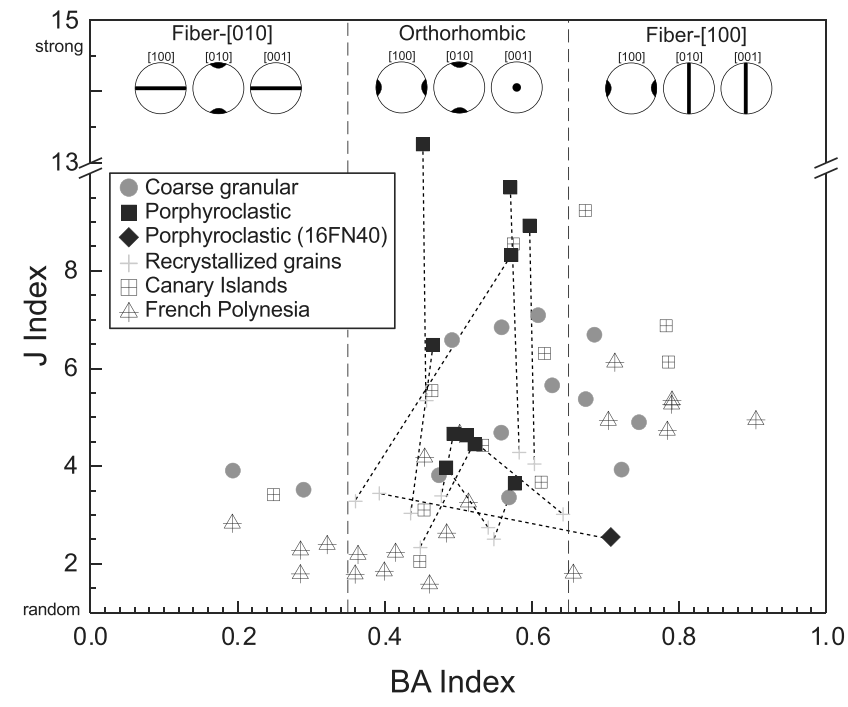

Figure 8. Olivine CPO symmetry (BA index) versus CPO strength (J index) in the Fernando de Noronha mantle xenoliths (data presented in Table 2). Similar data for mantle xenoliths from Canary Islands in the Atlantic Ocean (Vonlanthen et al., 2006) and French Polynesia in the Pacific Ocean (Tommasi et al., 2004) recalculated using MTEX with the same parameters as the present study (Table S3 in the supporting information) are shown for comparison. For the porphyroclastic peridotites, the CPO strength and symmetry of the recrystallized grains is compared to the one of the bulk rock. The variation in olivine CPO symmetry as a function of the BA index is illustrated at the top of the diagram. fiber-[010] CPO, whereas the bulk CPO has a symmetry intermediate between orthorhombic and fiber-[100]. In the remainder porphyroclastic peridotites, the variation in olivine CPO symmetry accompanying recrystallization is smaller: both the bulk rock and the recrystallized grains have orthorhombic patterns. Yet half of the samples show lower BA indexes for the recrystallized grains than for the bulk rock and only one sample is characterized by a higher BA index for the recrystallized grains (Figure 8).

Pyroxenes have on average more dispersed CPOs, which in many cases are not consistent with the olivine CPO (Figure 7). Correlated CPOs, suggesting coherent deformation of the three phases, are characterized by $[001]_{\mathrm{px}}$ maxima parallel or subparallel to the $[100]_{\mathrm{ol}}$ maximum and by $[100]_{\mathrm{opx}}$ and $[010]_{\mathrm{cpx}}$ maxima aligned with the $[010]_{\mathrm{ol}}$ maximum (arrows in Figure 7). Eight out of 13 of the coarse granular samples and 5 out of 11 of the porphyroclastic samples display well or partially correlated orthopyroxene and olivine CPO patterns. Nine out of 13 of the coarse granular samples and 4 out of 11 of the porphyroclastic samples show well or partially correlated clinopyroxene and olivine CPO patterns. Among these, 16FN05, 16FN12, 16FN29, and FN93-55 display well-correlated CPOs for all three phases. Pyroxenes with CPO noncorrelated with the olivine $\mathrm{CPO}$, either have very weak CPO or one to two maxima of [001] at high angle to the olivine [100] maximum.

\subsection{Mineral Compositions}

Chemical compositions of olivine, orthopyroxene, clinopyroxene, and spinel are presented in Figure 9. New data obtained in this study are listed in Table S1 in the supporting information. Data from Rivalenti et al. (2000) used in the present study are recalled Table S2 in the supporting information.

There is no clear relationship between the minerals' chemical compositions and the peridotites' microstructure. Within the studied FN peridotites, the $\mathrm{Mg} \#$ number $[\mathrm{Mg} \#=100 \times \mathrm{Mg} /(\mathrm{Fe}+\mathrm{Mg})$, atomic ratio] of olivine, ortho-pyroxene, and clinopyroxene ranges between 88.2-90.8 (average $=89.6$ ), 88.6-90.7 (average $=89.9$ ), and 88.0-91.9 (average $=89.8$ ), respectively. Within a sample, grain cores show almost equal Mg\# values for the three mineral phases (Figures 9a and 9b), except two samples (16FN29, FN50) that display higher $\mathrm{Mg \#}$ values for clinopyroxene than for olivine. Rim compositions show a higher dispersion within a sample than core ones, but a few samples (16FN01, 16FN05, 16FN19, 16FN32) also show high variability in core compositions indicating stronger chemical disequilibrium. Many samples show a weak variation in $\mathrm{Mg} \#$ values between cores and rims. The olivine $\mathrm{Mg} \#$ decreases and the orthopyroxene $\mathrm{Mg \#}$ increases from core to rim in samples $16 \mathrm{FN} 01,16 \mathrm{FN} 19$, and 16FN30, whereas the olivine Mg\# decreases from core to rim at constant orthopyroxene Mg\# in samples 16FN35 and 16FN37 (Figure 9b). Most samples show very small core-rim variations for the clino-pyroxene Mg\#, but samples 16FN19 and 16FN35 show higher Mg\# in the rims. Comparison of the present data set to the mineral compositions in abyssal peridotites from Mid-Atlantic Ridge (MAR; Warren, 2016) highlights that our samples display significantly lower Mg\# for all three minerals. Moreover, Mg\# values of clino-pyroxene in abyssal peridotites tend to be higher than the Mg\# of coexisting olivine, spreading between the 1:1 line and the Fe-Mg partition trend between olivine, clinopyroxene, and melt determined based on data in oceanic troctolites (Lissenberg \& Dick, 2008). There is no systematic variation of Ca content ( $\mathrm{ppm}$ ) in olivine as a function of olivine $\mathrm{Mg \# ,} \mathrm{but} \mathrm{rims} \mathrm{have} \mathrm{higher} \mathrm{and}$ more variable Ca contents than the cores in all samples (Figure 9c).

The $\mathrm{Cr}$ number $[\mathrm{Cr} \#=100 \times \mathrm{Cr} /(\mathrm{Cr}+\mathrm{Al})$, atomic ratio] of spinel rises with decreasing $\mathrm{Mg} \#$ of spinel. Spinels in FN peridotites display a similar trend to the one from abyssal peridotites from the MAR (Warren, 2016), but have systematically lower $\mathrm{Mg} \#$ at the same $\mathrm{Cr} \#$ (Figure 9d). $\mathrm{TiO}_{2}$ contents (wt \%) in spinel in FN peridotites range between 0.13 and $0.22 \%$, marking a clear enrichment in Ti relatively to MAR abyssal peridotites (Figure 9e). 

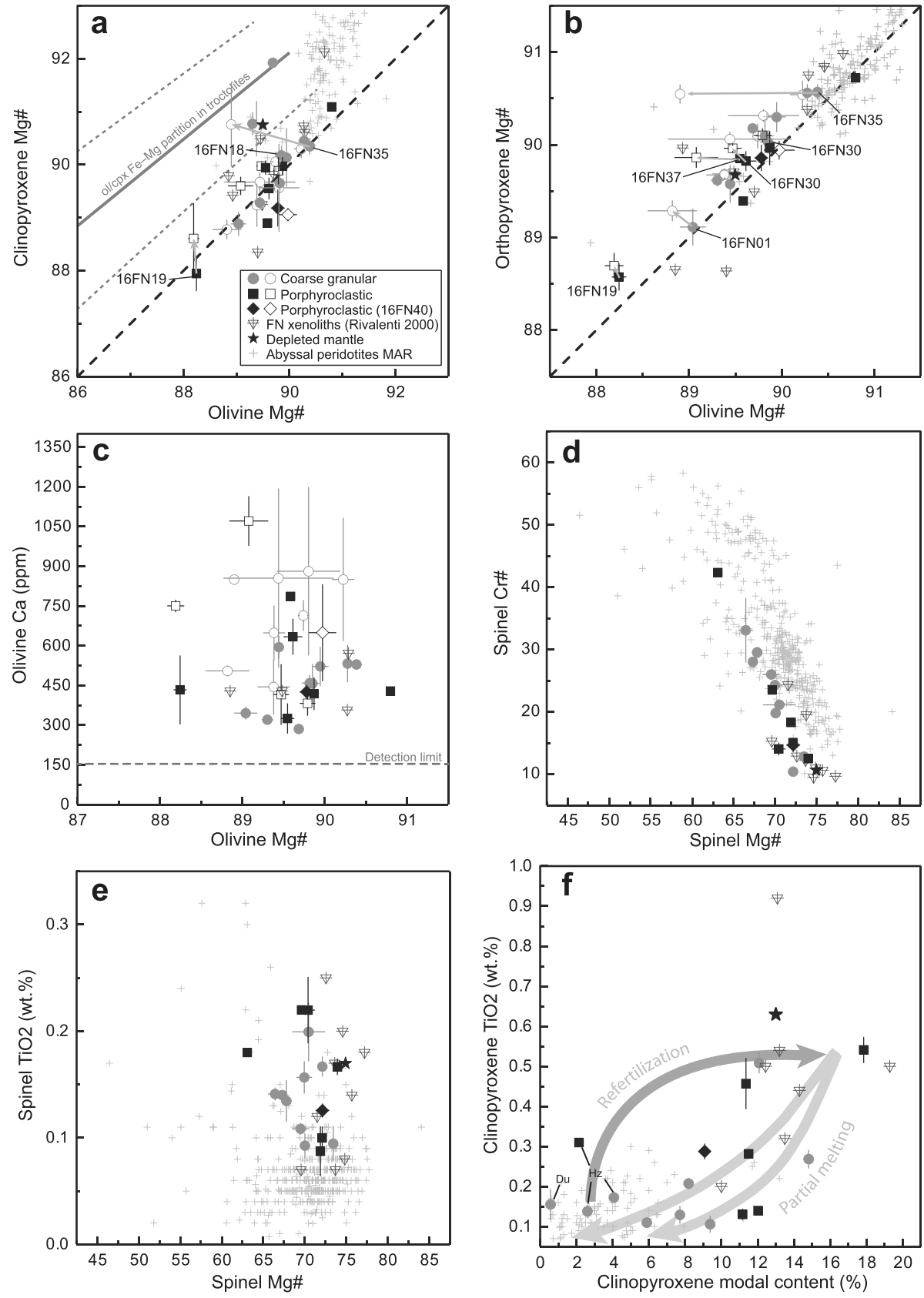

Figure 9. Chemical compositions of major rock-forming minerals in Fernando de Noronha peridotites. Error bars

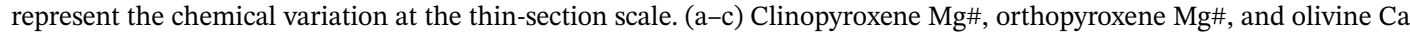
content ( $\mathrm{ppm}$ ) versus olivine Mg\#; solid symbols indicate core compositions and hollow symbols, rim compositions. (d and e) Spinel $\mathrm{Cr} \#$ and $\mathrm{TiO}_{2}$ content (wt \%) versus $\mathrm{Mg} \#$. (f) Clinopyroxene $\mathrm{TiO}_{2}$ content (wt \%) versus modal content (\%) compared to theoretical partial melting trends and to refertilization trends documented in Lherz by Le Roux et al. (2007). For comparison, data for FN mantle xenoliths from Rivalenti et al. (2000) are plotted on all diagrams. Mineral compositions for the depleted mantle (DM) and from abyssal peridotites from the Mid-Atlantic Ridge (MAR) compiled by Warren (2016) are plotted on (a), (b), (d), (e), and (f). Fe-Mg partition in troctolites from Lissenberg and Dick (2008) is plotted in (a). Gray arrows in (a) and (b) link core-rim pairs referred to in the text. Data presented in Table S1 in the supporting information. 

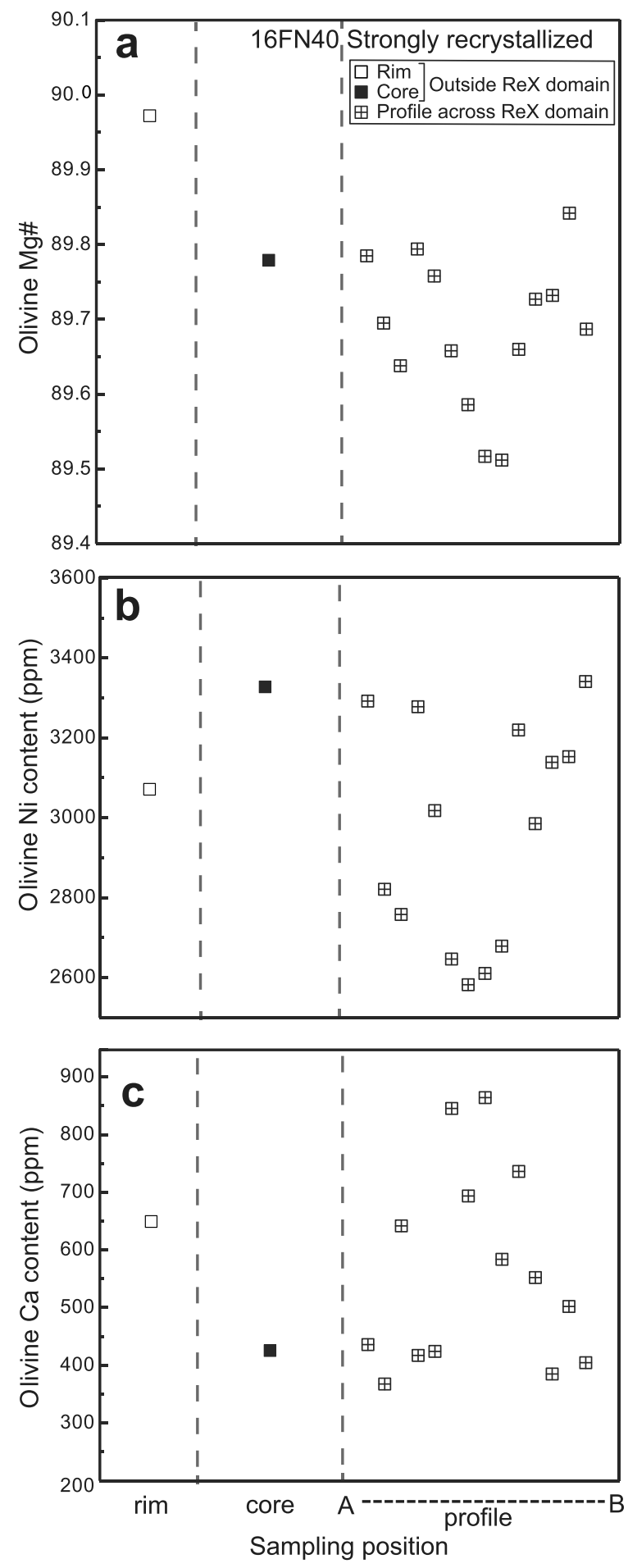

Figure 10. Variations in olivine (a) Mg\#, (b) Ni content (ppm), and (c) Ca content (ppm) along a profile across a recrystallized domain in strongly recrystallized porphyroclastic lherzolite (16FN40); core values in small $(<350-\mu \mathrm{m}$ wide) grains. Average core and rim values outside the recrystallized domain are plotted for comparison.
$\mathrm{TiO}_{2}$ contents in clinopyroxene in the lherzolites tend to increase with clinopyroxene modal content up to approximately $10-12 \%$ of clinopyroxene and to remain stable at approximately $0.5 \mathrm{wt} \%$ for higher clino-pyroxene contents. Clinopyroxene in harzburgites (16FN07, 16FN35, FN93-55) and in the dunite (16FN05) tends nevertheless to show higher or similar $\mathrm{TiO}_{2}$ content $(0.15-0.3 \mathrm{wt} \%)$ than lherzolites with $<10 \%$ cpx (Figure 9f).

As described in the previous section, the partially recrystallized porphyroclastic sample 16FN40 contains a fine-grained domain with a vein-like shape, composed of olivine, orthopyroxene, and clinopyroxene neoblasts (Figures 2, 4f, and 5f). In order to investigate the chemical variation between this fine-grained domain and the coarse grains that compose the remainder of the sample, we performed a line profile across the recrystallized domain (location of the profile is indicated in Figures $2 \mathrm{~b}$ and 4f). These analyses indicate that there is no clear variation in chemical compositions of orthopyroxene and clinopyroxene, but that the olivine composition changes (Figures 10a-10c). The data show a strong variability indicating disequilibrium at the millimeter scale, but there is a clear decrease of olivine $\mathrm{Mg \#}$ and $\mathrm{Ni}$ content (ppm) and increase of Ca content (ppm) toward the center of the fine-grained domain. A similar variation in composition is also observed between the cores and rims of coarse olivine grains outside the recrystallized domain.

\subsection{Equilibrium Temperatures and Geotherm Estimation}

Comparison between the equilibrium temperature for the cores and the rims calculated using the two-pyroxene geothermometer of Taylor (1998; TTA98) and the $\mathrm{Ca}$ in orthopyroxene (Ca-in-opx) of Brey and Kohler (1990) revised by Nimis and Grutter (2010) shows that the temperatures predicted by the two thermometers agree within the $\pm 70{ }^{\circ} \mathrm{C}$ error bar of these thermometers for most samples (Figure 11); this suggests that the temperature estimates are reliable. Three core temperature values (16FN01, FN6, FN50) and three rim temperatures (16FN01, 16 FN05, 16FN30) are slightly out of this range. These samples also show a high dispersion of the temperatures calculated using different grains in the sample, which further points toward chemical disequilibrium. In addition, 16FN19, which plots within the $\pm 70{ }^{\circ} \mathrm{C}$ confidence area, shows $\mathrm{a} \pm 110^{\circ} \mathrm{C}$ dispersion of the temperatures calculated with the TTA98 thermometer, consistently with the lack of equilibrium in cpx compositions in this sample (Figure 9a). We also recalculated equilibrium temperatures for the FN peridotites studied by Rivalenti et al. (2000) based on the published average pyroxenes compositions (Table $\mathrm{S} 2$ in the supporting information). This earlier data set defines a temperature range similar to the one obtained in the present study, but some samples show a marked difference between the temperatures predicted by the two thermometers, suggesting chemical disequilibrium.

The values calculated using the TTA98 thermometer are considered as the equilibrium temperature following the recommendation by Nimis and Grutter (2010). There is no clear correlation between the equilibrium temperatures and the microstructures (Figure 11). The equilibrium temperatures for the cores and the rims are concentrated between $860{ }^{\circ} \mathrm{C}$ and
$\mathrm{C}$, respectively. The rim temperatures usually show higher dispersion within than core ones, denoting cooling. Samples equilibrated at $>950{ }^{\circ} \mathrm{C}$ tend to display rim temperatures 


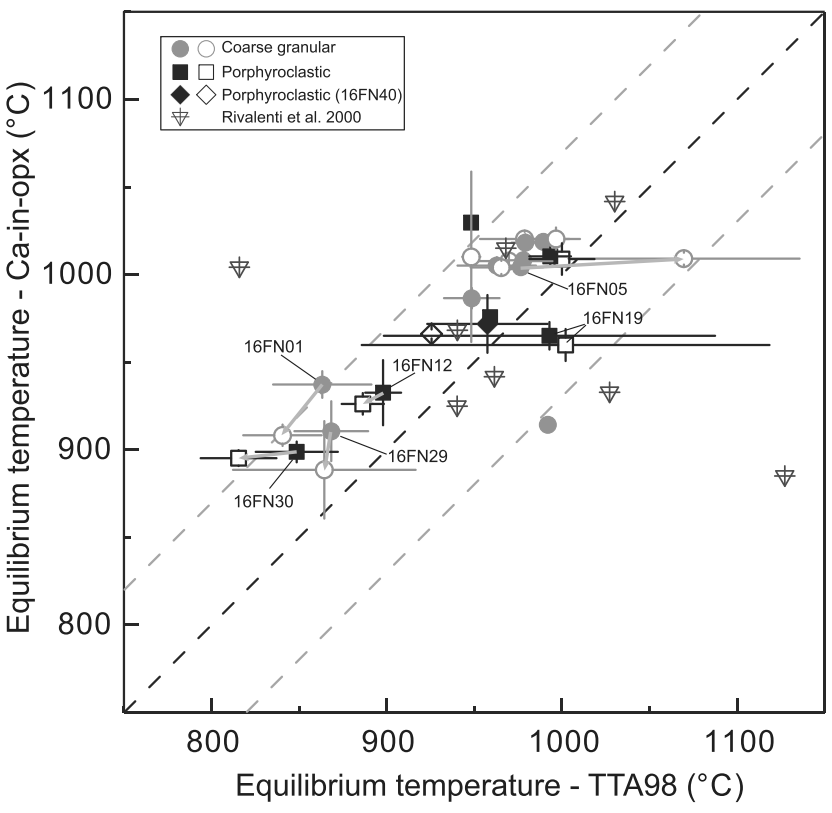

Figure 11. Average core and rim equilibrium temperatures calculated using the two-pyroxene thermometer (TTA98; Taylor, 1998) and the Ca-in-opx thermometer (Brey \& Kohler, 1990, revised by Nimis \& Grutter, 2010). Equilibrium temperatures for the peridotites previously studied by Rivalenti et al. (2000) were recalculated using the same methods based on published mineral chemistry (recalled in Table S2 in the supporting information). Error bars represent the variation in mineral chemistry at the thin section scale. Gray lines link core-rim pairs discussed in the main text. The black dashed line indicates equal predictions by the two thermometers, and the gray dashed lines define the $\pm 70{ }^{\circ} \mathrm{C}$ variation. similar to core ones, with exception of 16FN05, which shows a hotter rim temperature. However, the strong variability of rim temperatures in this sample indicates that rim compositions are not in equilibrium.

Geotherms estimated using three cooling models for a 100-Myr-old oceanic plate, i.e., the half-space cooling, a plate model with an 80 -km-thick plate and a $1300{ }^{\circ} \mathrm{C}$ mantle temperature (Turcotte \& Schubert, 2014), and the CHABLIS model (Doin \& Fleitout, 1996), are compared to the FN peridotites equilibration conditions in Figure 12. As no reliable barometers are available for spinel-facies peridotites, the equilibrium pressure range for the studied xenoliths is only defined by the occurrence of spinel and absence of plagioclase or garnet. These reactions depend on the fertility of the peridotite and on its $\mathrm{Cr}$ content (Klemme, 2004; O'Neill, 1981). Thus, P equilibrium conditions for FN peridotites are represented as bars, which length is a function of the sample spinel $\mathrm{Cr} \#$. All samples with equilibrium temperatures $<900{ }^{\circ} \mathrm{C}$ have low spinel $\mathrm{Cr} \#(\leq 15)$; the absence of garnet in these Al-rich, Cr-poor peridotites implies that they were equilibrated at pressures $\leq 1.5 \mathrm{GPa}$ (Figure 12). Samples equilibrated at temperatures $>900{ }^{\circ} \mathrm{C}$ have slightly higher spinel $\mathrm{Cr} \#$, but with exception of FN6 (spinel $\mathrm{Cr} \#=42$ ), all others have spinel $\mathrm{Cr} \# \leq 30$. The absence of garnet implies therefore that their equilibration depths remain shallow $(<60 \mathrm{~km}$; Figure 12). Considering the age of the crust of $100 \mathrm{Myr}$, the $P-T$ equilibration conditions of the FN peridotite xenoliths are better fitted by the CHABLIS model, which predicts a 75km-thick lithosphere beneath FN. The plate model predicts a slightly cooler geotherm, which results in an approximately $85-\mathrm{km}$-thick lithosphere. As expected for such old plate ages, the half-space model strongly overestimates both cooling and the lithosphere thickness; its predictions cannot be reconciled with the FN peridotite equilibration conditions.

\subsection{Seismic Properties}

Seismic properties for all samples were calculated at $900{ }^{\circ} \mathrm{C}$ and $1.72 \mathrm{GPa}$, which correspond to the average equilibrium temperature of the FN peridotites and the pressure at which this value is attained in a 100-Myrold oceanic plate for the CHABLIS model (Doin \& Fleitout, 1996). Seismic anisotropy patterns of the individual samples are similar as most samples show orthorhombic olivine CPO. However, seismic anisotropy intensities are variable due to changes in both the olivine content and intensity of olivine CPO among samples (Figure 13). The maximum $S$ wave polarization anisotropy varies between 4.1 and $9.6 \%$, but most data cluster between 4 and 6\% of anisotropy (Figure 13). The maximum propagation anisotropy for $P$ waves ranges between 4.3 and $12.9 \%$ (median at $6.4 \%$ ), whereas the maximum propagation anisotropy for fast (S1) and slow (S2) waves varies from 1.3 to $6.2 \%$ (median at $2.9 \%$ ) and from 1.9 to $7.3 \%$ (median at $4.1 \%$ ), respectively (Table 3).

Since seismic waves average elastic properties over large volumes, we averaged the elastic tensor constants of all samples (seismic properties for the individual samples are presented in Table S4 in the supporting information) using a common structural reference frame, with the assumption that most deformation in an oceanic domain takes place in the asthenosphere where olivine deforms by dislocation creep with dominant activation of the [100](010) systems (Tommasi, 1998; Tommasi et al., 2000). This hypothesis supposes, in absence of changes in the plate motion as it is the case for the equatorial Atlantic, a coherent deformation structure frozen in the entire lithospheric column (Tommasi, 1998). It results in an estimation of the maximum seismic anisotropy in the oceanic lithosphere mantle of this area (Figure 14).

$P$ wave velocities range between 8.1 and $7.6 \mathrm{~km} / \mathrm{s}$. $P$ waves propagate fastest in the direction of the lineation and slowest perpendicular to the foliation. The $S$ wave polarization anisotropy is the lowest at $\pm 20^{\circ}$ from the lineation (apparent isotropy directions) in the $x z$ plane and the highest (4.4\%) in the foliation plane, but at high angle to the lineation. Low $S$ wave polarization anisotropy $(\sim 1 \%)$ is detected for waves propagating parallel to the lineation. The fast split $S$ wave (S1) will be polarized parallel to the lineation for any propagation 


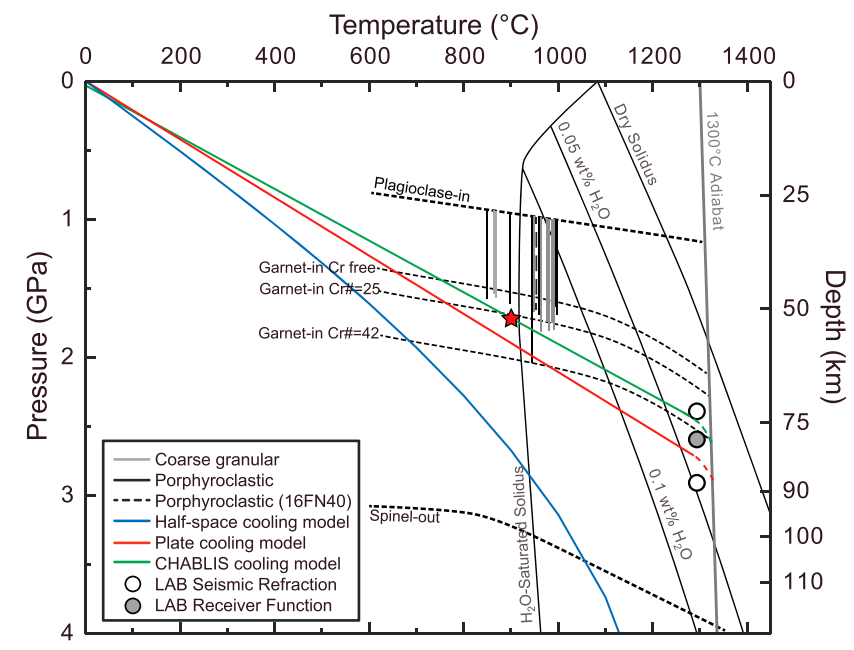

Figure 12. $P$ - $T$ diagram comparing the equilibration conditions estimated for the Fernando de Noronha mantle peridotites to geotherms predicted for a 100-Myr-old oceanic plate using three theoretical cooling models. As no barometers are available for spinel peridotites equilibrium pressure ranges are presented as bars, based on the absence of plagioclase and of garnet in the studied peridotites, considering their $\mathrm{Cr} \#$ (Table $\mathrm{S} 1$ in the supporting information) and the effect of $\mathrm{Cr}$ on the spinel-garnet phase transition. Phase transitions after Klemme (2004) and O'Neill (1981). Dry and wet solidus with variable $\mathrm{H}_{2} \mathrm{O}$ contents after Ringwood (1975). The red star marks the $P$ - $T$ condition $\left(900^{\circ} \mathrm{C}, 1.72 \mathrm{GPa}\right.$ ) used for the seismic property calculations. White and gray circles indicate lithosphere-asthenosphere boundary (LAB) depths predicted by seismic refraction (Mehouachi and Singh, 2018) and receiver function (Rychert et al., 2018) studies in the equatorial Atlantic. direction. S1 waves velocities range between 4.6 and $4.5 \mathrm{~km} / \mathrm{s}$; they are fastest for propagation within the foliation plane at approximately $45^{\circ}$ to the lineation and slowest for propagation perpendicular to the foliation. Propagation directions at low and high angle to the lineation sample on average low S1 velocities. The maximum anisotropy of Vs1 is $2.2 \%$. S2 waves have the lowest velocity within the plane normal to the lineation $(4.35 \mathrm{~km} / \mathrm{s})$ and the highest velocity at low angle to the lineation in the $x z$ plane $(4.5 \mathrm{~km} / \mathrm{s})$. The maximum anisotropy of Vs2 is $3.4 \%$. The $\mathrm{Vp} / \mathrm{Vs} 1$ ratio is the highest (1.8) when the waves propagate parallel to the lineation and the lowest (1.7) when they propagate normal to the foliation. The maximum anisotropy of the $\mathrm{Vp} / \mathrm{Vs} 1$ ratio is $3.4 \%$.

\section{Discussion}

\subsection{Composition of the Deep Oceanic Lithosphere}

FN peridotites are significantly more fertile than Mid-Atlantic Ridge abyssal peridotites (Figure 9). The higher fertility may result from a lower degree of partial melting, consistently with the fact that the FN xenoliths sample asthenospheric material accreted to the lithospheric mantle by cooling far from the mid-ocean ridge. By consequence, this material has seen less decompression and should not have been submitted to large degrees of partial melting. However, if this was the only process controlling the composition of the lithospheric mantle, FN peridotites should have compositions ranging between those of the depleted mantle (black star) and the abyssal peridotites (gray crosses) along the trend defined by the partial melting models in Figure 15. However, very few of the FN xenoliths plot along this trend. Most samples plot below the partial melting curves (Figure 15), indicating that they are enriched in Fe (low Mg\#) and, in some cases, in olivine. These compositions may be produced by reactive melt percolation of low $\mathrm{Mg} \#$ basaltic melts leading to dunitization (Bodinier \& Godard, 2014; dashed green lines in Figure 15, where the numbers indicate the melt $\mathrm{Mg} \#$ ) or by melt-rock interaction with or without pyroxene crystallization, but in which the melt composition continuously changes as the result of earlier reaction stages (Bodinier et al., 2008, dashed blue lines in Figure 15). A few FN xenoliths plot above the partial melting trend, indicating enrichment in pyroxenes; these compositions may be produced by refertilization reactions during reactive melt percolation (Bodinier \& Godard, 2014; thin red lines in Figure 15, where the numbers indicate the mass ratio of crystallized minerals to infiltrated melt). Indeed, many lherzolites (e.g., 16FN12, 16FN18, 16FN21) are characterized by clinopyroxene and a few (16FN18, 16FN21) by orthopyroxene enrichment relatively to the predictions of partial melting models (Figure 2b) and the

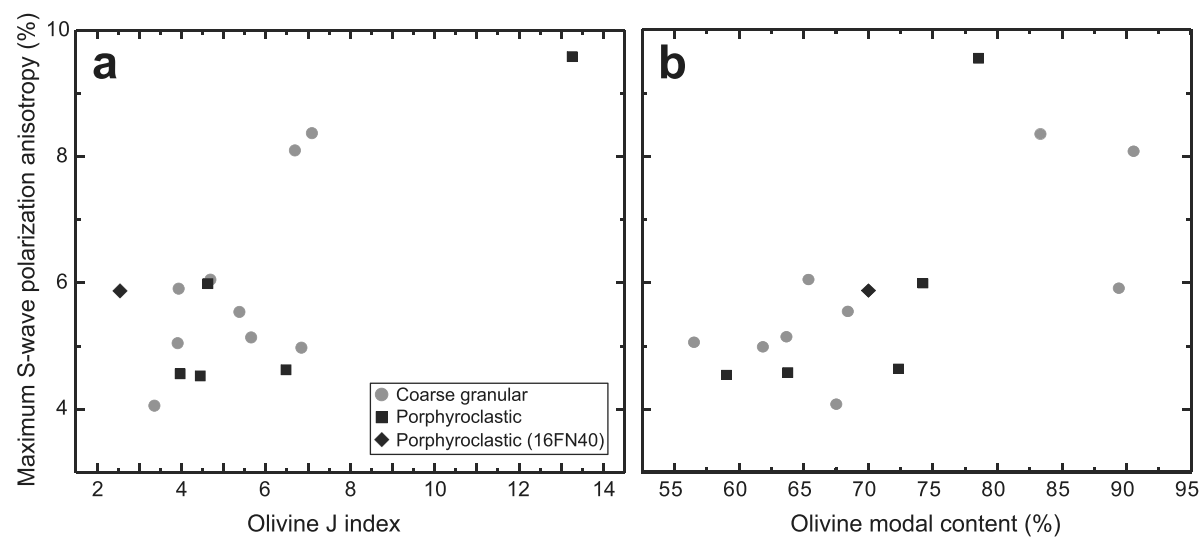

Figure 13. Maximum $S$ wave polarization anisotropy (\%) of individual samples versus (a) olivine CPO strength (J index) and (b) olivine modal content (\%). 
Table 3

Calculated Seismic Properties at $900{ }^{\circ} \mathrm{C}$ and $1.72 \mathrm{GPa}$ for Individual Samples and for the Average of All FN Peridotites

\begin{tabular}{|c|c|c|c|c|c|c|c|c|c|c|c|c|c|c|c|c|c|c|c|}
\hline \multirow[b]{2}{*}{ Sample } & \multirow[b]{2}{*}{$\begin{array}{l}\text { Rock } \\
\text { Type }\end{array}$} & \multirow{2}{*}{\multicolumn{2}{|c|}{$\begin{array}{l}\text { Microstructure/ } \\
\text { Rex Fraction } \\
\text { (\%) }\end{array}$}} & \multicolumn{16}{|c|}{ Seismic Properties (Velocity in km/s and Anisotropy in \%) } \\
\hline & & & & $\mathrm{AVp}$ & $\begin{array}{l}\text { Vp } \\
\text { Max }\end{array}$ & $\begin{array}{l}\text { Vp } \\
\text { Min }\end{array}$ & AVs & AVs1 & $\begin{array}{l}\text { Vs1 } \\
\text { Max }\end{array}$ & $\begin{array}{l}\text { Vs1 } \\
\text { Min }\end{array}$ & AVs2 & $\begin{array}{l}\text { Vs2 } \\
\text { Max }\end{array}$ & $\begin{array}{l}\text { Vs2 } \\
\text { Min }\end{array}$ & $\begin{array}{c}\mathrm{AVp} / \\
\mathrm{Vs} 1\end{array}$ & $\begin{array}{l}\text { Vp/ } \\
\text { Vs1 } \\
\text { Max }\end{array}$ & $\begin{array}{l}\text { Vp/ } \\
\text { Vs1 } \\
\text { Min }\end{array}$ & $\begin{array}{c}\mathrm{AVp} / \\
\mathrm{Vs} 2\end{array}$ & $\begin{array}{l}\text { Vp/ } \\
\text { Vs2 } \\
\text { Max }\end{array}$ & $\begin{array}{l}\text { Vp/ } \\
\text { Vs2 } \\
\text { Min }\end{array}$ \\
\hline 16FN01 & $\mathrm{Lz}$ & CG & & 5.7 & 8.2 & 7.7 & 5.1 & 3.6 & 4.6 & 4.5 & 4.5 & 4.6 & 4.4 & 6.6 & 1.8 & 1.7 & 4.8 & 1.8 & 1.7 \\
\hline 16FN05 & $\mathrm{Du}$ & CG & & 10.3 & 8.5 & 7.6 & 8.1 & 2.9 & 4.7 & 4.5 & 7.3 & 4.6 & 4.3 & 10.0 & 1.8 & 1.7 & 5.1 & 1.9 & 1.8 \\
\hline 16FN07 & $\mathrm{Hz}$ & CG & & 9.0 & 8.3 & 7.6 & 5.9 & 2.9 & 4.6 & 4.5 & 5.3 & 4.5 & 4.3 & 8.3 & 1.8 & 1.7 & 4.9 & 1.9 & 1.8 \\
\hline 16FN16 & $\mathrm{Lz}$ & CG & & 8.4 & 8.2 & 7.6 & 6.0 & 3.4 & 4.6 & 4.5 & 4.7 & 4.5 & 4.3 & 6.8 & 1.8 & 1.7 & 5.3 & 1.8 & 1.7 \\
\hline 16FN18 & $\mathrm{Lz}$ & CG & & 6.0 & 8.0 & 7.6 & 5.0 & 4.4 & 4.6 & 4.4 & 1.9 & 4.5 & 4.4 & 2.2 & 1.7 & 1.7 & 5.8 & 1.8 & 1.7 \\
\hline $16 \mathrm{FN} 29$ & $\mathrm{Lz}$ & CG & & 6.5 & 8.2 & 7.6 & 5.5 & 2.2 & 4.6 & 4.5 & 4.1 & 4.5 & 4.3 & 5.3 & 1.8 & 1.7 & 4.4 & 1.8 & 1.7 \\
\hline $16 \mathrm{FN} 32$ & $\mathrm{Lz}$ & CG & & 4.7 & 8.1 & 7.7 & 4.1 & 1.3 & 4.6 & 4.5 & 3.3 & 4.5 & 4.4 & 5.0 & 1.8 & 1.7 & 2.4 & 1.8 & 1.7 \\
\hline 16 FN35 & $\mathrm{Hz}$ & CG & & 12.1 & 8.5 & 7.5 & 8.4 & 4.7 & 4.7 & 4.5 & 7.3 & 4.6 & 4.2 & 12.1 & 1.8 & 1.6 & 7.1 & 1.9 & 1.8 \\
\hline FN50 & $\mathrm{Lz}$ & CG & & 4.5 & 8.0 & 7.7 & 5.0 & 4.2 & 4.6 & 4.4 & 3.2 & 4.5 & 4.4 & 4.4 & 1.8 & 1.7 & 4.9 & 1.8 & 1.7 \\
\hline $16 \mathrm{FN} 12$ & $\mathrm{Lz}$ & Porph & 14 & 4.3 & 8.0 & 7.7 & 4.6 & 3.6 & 4.6 & 4.5 & 2.1 & 4.5 & 4.4 & 4.6 & 1.8 & 1.7 & 3.8 & 1.8 & 1.7 \\
\hline 16FN19 & $\mathrm{Lz}$ & Porph & 26 & 5.7 & 8.1 & 7.6 & 4.6 & 2.0 & 4.6 & 4.5 & 3.2 & 4.5 & 4.4 & 4.8 & 1.8 & 1.7 & 3.2 & 1.8 & 1.7 \\
\hline 16 FN30 & $\mathrm{Lz}$ & Porph & 18 & 6.4 & 8.2 & 7.7 & 4.5 & 2.5 & 4.6 & 4.5 & 3.7 & 4.5 & 4.4 & 6.4 & 1.8 & 1.7 & 3.7 & 1.8 & 1.8 \\
\hline 16 FN37 & $\mathrm{Lz}$ & Porph & 12 & 8.8 & 8.2 & 7.6 & 6.0 & 2.9 & 4.6 & 4.5 & 4.8 & 4.5 & 4.3 & 7.8 & 1.8 & 1.7 & 4.6 & 1.8 & 1.7 \\
\hline FN6 & $\mathrm{Lz}$ & Porph & 15 & 6.1 & 8.2 & 7.7 & 4.6 & 3.4 & 4.7 & 4.5 & 3.1 & 4.5 & 4.4 & 6.1 & 1.8 & 1.7 & 5.0 & 1.8 & 1.7 \\
\hline FN93-55 & $\mathrm{Hz}$ & Porph & 14 & 12.9 & 8.4 & 7.4 & 9.6 & 6.2 & 4.7 & 4.4 & 6.4 & 4.5 & 4.3 & 9.7 & 1.8 & 1.7 & 8.8 & 1.9 & 1.7 \\
\hline $16 \mathrm{FN} 40$ & $\mathrm{Lz}$ & Porph & 46 & 7.5 & 8.2 & 7.6 & 5.9 & 1.7 & 4.6 & 4.5 & 4.8 & 4.5 & 4.3 & 6.4 & 1.8 & 1.7 & 3.6 & 1.8 & 1.8 \\
\hline Average & - & - & & 6.2 & 8.1 & 7.6 & 4.4 & 2.2 & 4.6 & 4.5 & 3.4 & 4.5 & 4.4 & 5.2 & 1.8 & 1.7 & 3.3 & 1.8 & 1.8 \\
\hline
\end{tabular}

Note. $\mathrm{AVp}=$ maximum $P$ wave propagation anisotropy; $\mathrm{AVs}=$ maximum $S$ wave polarization anisotropy; AVs1 = maximum propagation anisotropy for the fast $S$ wave; AVs2 = maximum propagation anisotropy for the slow $S$ wave; $\mathrm{AVp} / \mathrm{Vs} 1=$ maximum anisotropy of the Vp/Vs1 ratio; $\mathrm{AVp} / \mathrm{Vs} 2=\mathrm{maximum}$ anisotropy of the $\mathrm{Vp} / \mathrm{Vs} 2$ ratio; $\mathrm{Lz}=$ lherzolite; $\mathrm{CG}=$ coarse-granular; $\mathrm{Du}=$ dunite; $\mathrm{Hz}=$ harzburgite; Porph = porphyroclastic.

${ }^{\mathrm{a}}$ Samples from Rivalenti et al. (2000).

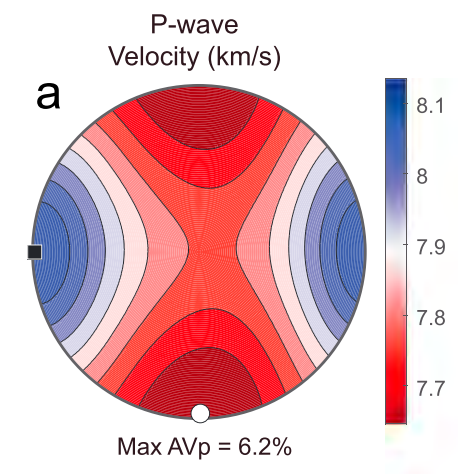

S1-wave Velocity $(\mathrm{km} / \mathrm{s})$

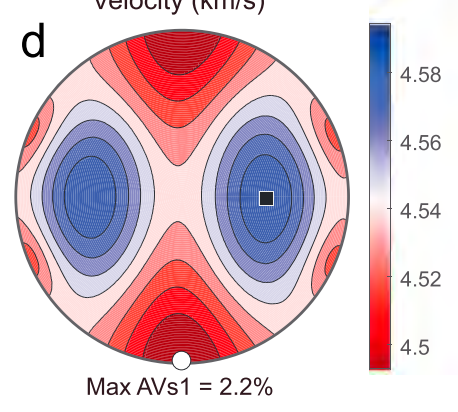

S-wave Polarization anisotropy (\%)

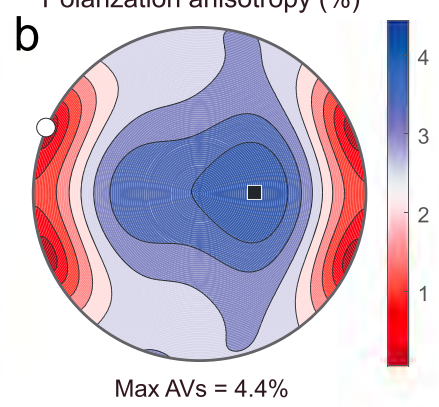

Max

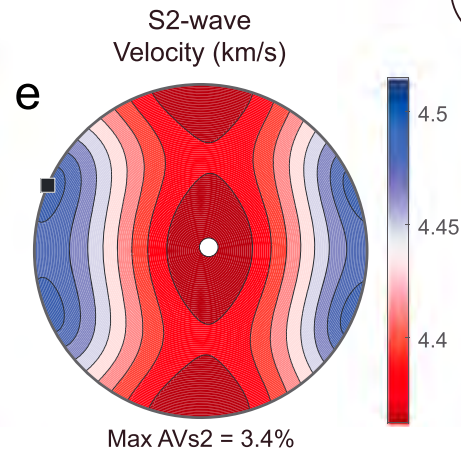

S1-wave

Polarization planes
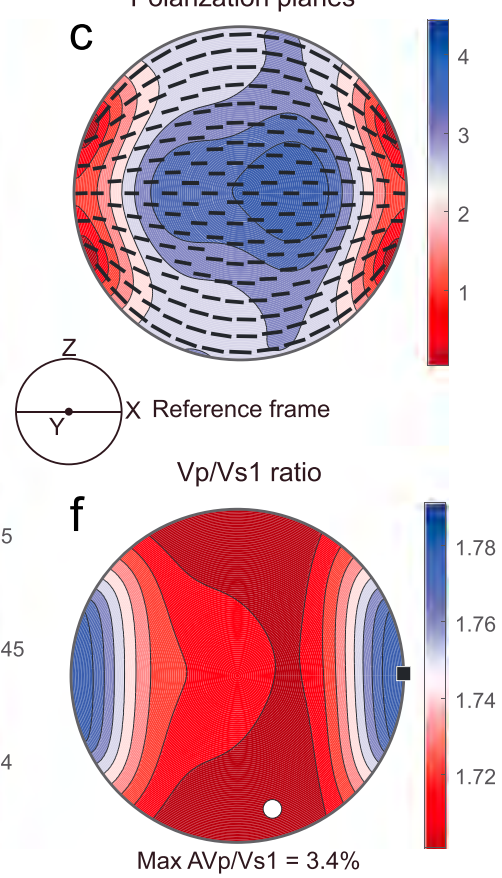

Figure 14. Average seismic properties for the lithospheric mantle beneath Fernando de Noronha at $900{ }^{\circ} \mathrm{C}$ and $1.72 \mathrm{GPa}(\sim 50-\mathrm{km}$ depth; cf. Fig. 12$)$. (a) $P$ wave velocities (Vp; km/s). (b) $S$ wave polarization anisotropy (AVs $=200 \times(\mathrm{Vs} 1-\mathrm{Vs} 2) /(\mathrm{Vs} 1+\mathrm{Vs} 2)$ in \%). (c) Direction of fast S1 wave polarization planes. (d) S1 wave velocities (Vs1; km/s). (e) S2 wave velocities (Vs2; km/s). (f) Vp/Vs1 ratio. Lower hemisphere stereographic projections presenting the variation of the property as a function of the propagation direction relatively to the structural reference frame (flow direction $(x)$ and normal to the flow plane $(z)$, shown by the insert in the middle right of the figure). Black squares indicate the highest values and white circles, the lowest ones. 


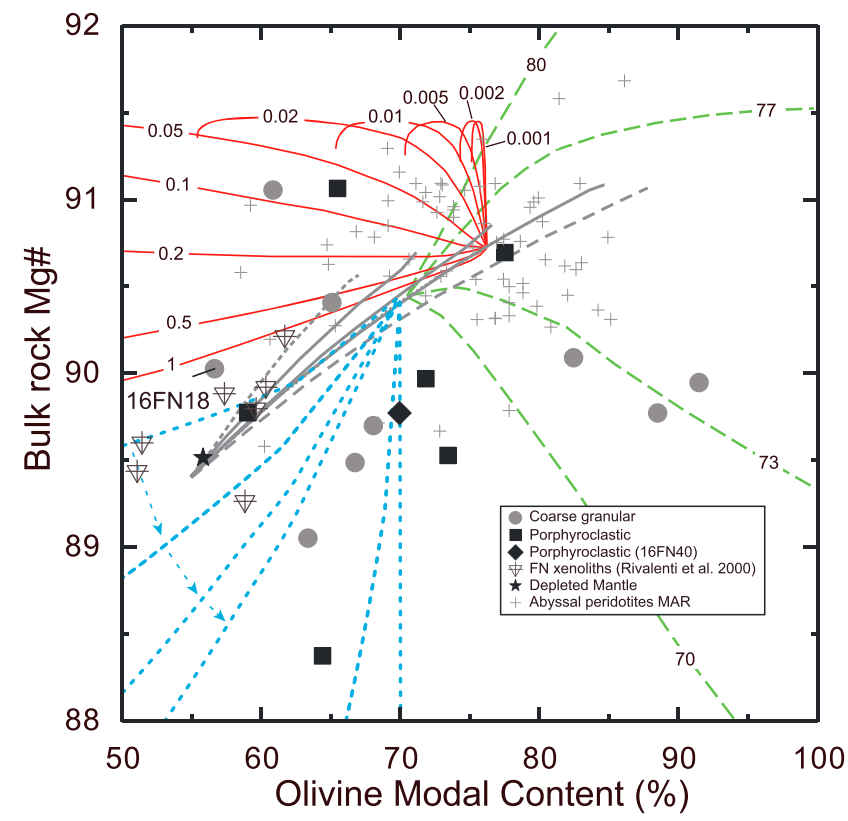

Figure 15. Olivine modal content (\%) versus bulk rock Mg\# in Fernando de Noronha peridotites compared to evolutions predicted for partial melting and reactive melt percolation in the mantle. Gray lines represent the composition evolution predicted by various partial melting models using a source composition with 55\% of olivine and Mg\# of 89.3 up to complete consumption of clinopyroxene (Bodinier \& Godard, 2014). Colored lines represent different melt-rock reactions after Bodinier \& Godard (2014). Red solid lines correspond to precipitation of clinopyroxene and orthopyroxene at the expense of olivine and melt with different mass ratio of crystallized minerals versus infiltrated melt (numbers of the top of the curves). Green dashed lines show olivine-forming reactions with melts with different $\mathrm{Mg} \#$ (numbers of the top of the curves). Blue dotted lines represent multiple episodes of refertilization, starting with low $\mathrm{Mg} \#$ melts ("primitive" melt Mg\# = 74.5), in which the peridotites successively reacted with the evolved melt resulting from previous infiltration stage (Bodinier et al., 2008).

Compositions of FN peridotites previously studied by Rivalenti et al. (2000), depleted mantle (DM), and abyssal peridotites from Mid-Atlantic Ridge (MAR; Warren, 2016) are plotted for comparison. two coarse granular harzburgites (16FN07 and 16FN35) and the dunite (16FN05) are characterized by olivine enrichment (Figures $2 \mathrm{~b}$ and 15).

Petrographic and other chemical evidence further imply variable meltrock interaction leading to changes in modal and chemical compositions of FN peridotites. The petrographic evidence encompasses interpenetrating olivine-pyroxene grain boundaries, the cusp shapes of pyroxene grain boundaries when in contact with two olivine grains, and the interstitial shapes of small pyroxenes (Figures 4 and 5). These features are observed in both coarse-granular and porphyroclastic peridotites, but they are best expressed in the porphyroclastic peridotites. Additional chemical evidence for reactive melt percolation in both coarse granular and porphyroclastic peridotites includes $\mathrm{Ti}$ enrichment in spinel and clinopyroxene (Figures 9e and 9f) and $\mathrm{Ca}$ enrichment in some olivine cores and in all rims (Figure 9c). Enrichment in $\mathrm{Ca}$ and $\mathrm{Fe}$ and depletion in $\mathrm{Ni}$ in olivine in the center of the fine-grained recrystallized domain and in the rims in lherzolite 16FN40 (Figure 10) imply increased reactive melt percolation in this domain. In addition, the lack of or the only partial correlation between olivine and pyroxene CPO (Figure 7), which also characterizes both microstructures, suggests that at least part of the pyroxenes may have crystallized after the deformation has ceased.

Why and when did these melt-rock reactions occur? They may result from (1) continuous percolation of small fractions of melt from the asthenosphere into the base of the oceanic plate as the latter cools and thickens with time (Process 1) and/or (2) localized percolation of larger volumes of melt associated with Cenozoic alkaline volcanism and related dikes leading to the formation of the volcanic islands (Process 2). The first process corresponds to a protracted percolation history, which may produce limited refertilization of the base of the lithosphere in a continuous mode, as it cools and thickens with increasing aging and, hence, distance from the ridge (Figure 16). This process is, for instance, recorded by the presence of lherzolites at the base of the mantle section in the Oman ophiolite (Godard et al., 2000). Yet infiltration and freezing of small melt volumes into the cooling lithospheric plate cannot explain the marked enrichment in Fe in olivine relative to partial melting models that characterize some FN peridotites (Figure 15). Such an enrichment may only be produced

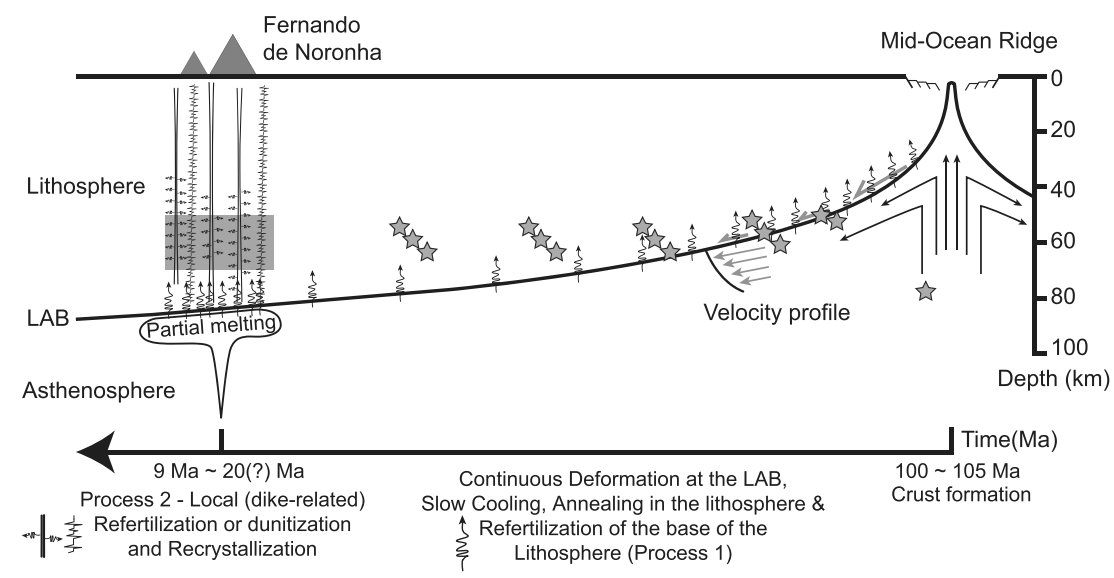

Figure 16. Schematic diagram depicting the proposed evolution for the studied oceanic mantle section. The horizontal axis represents time (not to scale). Gray stars and rectangle represent predicted positions of the xenoliths at different times. The lithosphere-asthenosphere boundary (LAB) evolution corresponds to the CHABLIS model prediction. 
by high time-integrated melt-rock ratios and/or a continued reaction history, which are more likely achieved in the vicinity of melt channels or dikes (Bodinier et al., 2008). These rocks probably record the percolation of the melts associated with the formation of the FN island (Process 2). In such an environment, the association of pervasive and localized melt percolation may produce a wide range of compositional signatures as it results in a large spatial variability of the melt-rock ratios. Reactions characterized by very high timeintegrated melt-rock ratios may be produced in the walls of dikes feeding the surface volcanism. The most extreme compositional changes affect therefore small volumes of the mantle $(<1 \mathrm{~m}$ away from the dike; Bodinier et al., 2008) at each diking episode, but repeated diking episodes may result in significant volumes of chemically modified lithospheric mantle beneath a large volcanic island, which may be sampled by latestage island volcanism.

In summary, FN mantle xenoliths show compositions that point to variable modification of a rather fertile mantle by reactive melt percolation. There is clear chemical evidence for reactions involving high melt-rock ratios and hence for changes directly associated with the Fernando de Noronha magmatism, independently on the origins of the latter (plume or a more diffuse mantle upwelling with focusing of the melt transport to the surface by lithospheric structures, such as fossil transforms). In addition, there is evidence pointing to "recent" melt-rock interaction, which is also consistent with Process 2 . This evidence includes the chemical disequilibrium recorded by many samples (core-rim compositional gradients and compositional variations in both cores and rims for fast-diffusing species such as Fe and $\mathrm{Mg}$ in pyroxenes and olivine or Ca in olivine at the thin section scale; Figure 9). Moreover, the clear spatial correlation between changes in olivine composition and the fine-grained domains in lherzolite 16FN40 (Figure 10) suggests that the development of fine-grained domains with irregular, vein-like shapes in the porphyroclastic peridotites is also related to "recent" melt percolation.

Is there also evidence for Process 1? Melt-rock reactions in peridotites leading to either pyroxene crystallization at the expenses of olivine or vice versa result in interpenetrating olivine-pyroxene grain boundaries. Pyroxene-rich lherzolites (16FN18, 16FN21) from the coarse granular group have well equilibrated pyroxene grain shapes (Figures 2, 4a, 4b, 5a, and 5b), which indicate that long-range solid-state diffusion (millimeter scale) allowing for re-equilibration of pyroxene grain shapes, followed refertilization. If melt-rock reactions occurred shortly before the extraction, this would not have been possible. This suggests that the refertilization recorded by these samples results from an older melt percolation process, such as Process 1 . It is noteworthy that orthopyroxene-rich lherzolite 16FN18 has olivine and pyroxene compositions similar to primitive mantle ones (Table 2).

In conclusion, we propose that both processes (Figure 16) have occurred in the oceanic lithosphere beneath the Fernando de Noronha archipelago, but that only the localized melt percolation associated with the island formation (Process 2) produced significant Fe enrichment, dunitization, and marked grain refinement. These processes probably affect small volumes of the lithospheric mantle, being limited to domains underlying the oceanic islands.

\subsection{Microstructural and CPO Evolution}

Porphyroclastic peridotites preserve clear evidence for deformation by dislocation creep. Olivine has common undulose extinction and subgrain boundaries (Figures 4 and 5). It displays strong to moderate orthorhombic CPO patterns with stronger concentrations of [100] and [010] relatively to [001], which imply dominant activation of the [100](010) slip system (Figures 7 and 8a). These features are characteristic of deformation at high-temperature, low-pressure, and low- to moderate-stress conditions. The coarse grain sizes (Figure 3) also point to low-stress conditions. Decrease in the strength of the olivine CPO is associated with the formation of fine-grained domains (Figure 8b), which, when they are well developed, such as in 16FN40, are characterized by change in olivine compositions. This suggests that the crystallization of fine grains is associated with reactive melt percolation, which may result in recrystallization of the existing coarse minerals and in neo-crystallization from the melt. Both processes produce dispersion of the olivine CPO. The preservation of chemical disequilibrium at the millimeter scale indicates that this process is recent, being probably related to the volcanism that formed the island; it should affect therefore limited volumes of the lithospheric mantle. It is noteworthy that comparison between the CPO of the recrystallized domains and of the bulk rock in strongly recrystallized peridotite 16FN40 highlights that the recrystallized domains have olivine CPO with a stronger fiber-[010] tendency. This change in olivine CPO pattern is 
consistent with previous observations on peridotites deformed in presence of melts both in nature and experiments (Higgie \& Tommasi, 2012, 2014; Qi et al., 2018). Weak fiber-[010] olivine CPO was also described in troctolites formed by reactive melt percolation in the shallow mantle beneath the MidAtlantic Ridge (Drouin et al., 2010).

Coarse granular peridotites have more re-equilibrated grain shapes and weaker intracrystalline misorientations than porphyroclastic ones. All coarse-granular peridotites display clear olivine CPO, supporting deformation by dislocation creep with dominant activation of [100](010). However, olivine CPO intensities are on average lower than those of porphyroclastic peridotites and olivine CPO patterns are more variable, (Figure 8a). These observations imply variable degrees of annealing following the deformation. The two most annealed coarse-granular lherzolites (16FN18 and 16FN21) show fiber-[010] patterns, low J index, and rather high equilibrium temperatures. However, there is neither a systematic correlation of annealing degree with equilibrium temperature (Figure 11), nor with chemical composition.

Pyroxene CPOs in many peridotites from both groups are either only partially correlated or uncorrelated with the olivine CPO (Figure 7). Most uncorrelated pyroxene CPOs are very dispersed. Pyroxene crystallization under static conditions should not result in CPO. By consequence, it should disperse the original, deformation-related CPO of the primary pyroxenes. The poor correlation between pyroxenes and olivine CPO therefore indicates that refertilization occurred after last main deformation episode, that is, after the incorporation of the peridotites to the lithosphere. Olivine-pyroxene grain boundaries are very sinuous in porphyroclastic peridotites, supporting a recent refertilization, probably associated with the volcanism forming the islands. Pyroxenes in coarse-granular peridotites have more equilibrated grain shapes, suggesting that annealing succeeded refertilization.

Peridotites from Canary Islands in the central Atlantic (Vonlanthen et al., 2006) show, similarly to the FN peridotites, dominantly orthorhombic olivine CPO patterns with highly variable strength (Figure 8). In contrast, mantle xenoliths from French Polynesia (Tommasi et al., 2004), which sample the Pacific oceanic lithosphere, have two olivine CPO pattern groups, which only weakly overlap the Atlantic oceanic lithosphere data (Figure 8). Coarse porphyroclastic lherzolites and harzburgites have strong to moderate olivine CPO (J index between 4.5 and 6.5) with dominantly fiber-[100] patterns, whereas the dunites and wehrlites, which are characterized by annealed microstructures and strong Fe enrichment, have very weak orthorhombic to fiber-[010] olivine CPO patterns (Figure 8). These observations further point to the role of reactive melt percolation, which in the French Polynesia resulted in dunitization under static conditions, on the dispersion and change of symmetry of olivine CPO patterns (Tommasi et al., 2004).

To conclude, we argue that deformation of FN mantle xenoliths occurred essentially at the LAB due to differential motion between the plate and the convective mantle (Figure 16). This high-temperature, low-stress deformation was mainly accommodated by dislocation creep in olivine with dominant activation of [100] (010). The deformation ceased gradually as the plate cooled down and the LAB progressively deepened with time, leading to fossilization of the deformation microstructures and CPOs in the lithospheric mantle. Annealing occurred in a continuous way after deformation, recovering the deformation microstructures, but mostly preserving the CPO. Annealing rates decreased with cooling of the lithosphere. Refertilization or dunitization during reactive melt percolation related to the volcanism forming the islands (Process 2) produced in contrast dispersion of the olivine CPO associated with the development of the fine-grained domains in porphyroclastic peridotites. In addition, refertilization reactions resulted in inconsistency between olivine and pyroxene CPOs.

\subsection{Comparison With Seismological Data From the Atlantic}

Two recent seismic studies have investigated the lithosphere-asthenosphere boundary (LAB) depth in the equatorial Atlantic northeast from the Fernando de Noronha Island. Based on refraction data, Mehouachi and Singh (2018) proposed a LAB at approximately $88 \mathrm{~km}$ for the 70-Myr-old oceanic plate north of the St. Paul fracture zone and at approximately $72 \mathrm{~km}$ for the 40 -Myr-old oceanic plate south of it. Receiver function data from the Passive Imaging of the Lithosphere-Asthenosphere Boundary (PILAB) experiment deployed across the equatorial Atlantic ridge around the Romanche fracture zone suggest a LAB, which deepens from 30- to 80-km depth beneath 0- to 40-Myr-old plate domains (Rychert et al., 2018). Surface wave data over the entire experiment area, which encompasses seafloor of 0-80 Myr old, produced a 1-D 
average model characterized by a $60-\mathrm{km}$-thick fast velocity lid. These results, in particular the fast thickening of the plate at young ages, are more consistent with the thermal evolution estimated using the plate model, but they may also be explained by the CHABLIS model that better fits the equilibrium data of the FN xenoliths (Figure 12).

The average seismic anisotropy estimated based on FN mantle xenolith compositions, CPO, and equilibrium temperatures may be compared with available seismological data in the Atlantic Ocean. Gaherty et al. (2004) analyzed seismic refraction data from the FAIM experiment in the western part of the central Atlantic. They observed faster propagation of $P$ waves parallel to the paleospreading direction and a $P$ wave anisotropy of $3.4 \pm 0.3 \%$. This observation is consistent with the predicted $P$ wave anisotropy for the average FN peridotite if both the lineation and the foliation are horizontal (Figure 14), as expected for deformation in the asthenosphere controlled by a velocity gradient between the plate and the underlying mantle (Tommasi, 1998). A vertical foliation, which may be expected in the shallow lithospheric mantle in the vicinity of a transform fault, would produce a higher $P$ wave anisotropy (6.2\%; Figure 14).

Anisotropic surface wave tomography in the Atlantic by Silveira and Stutzmann (2002) points to positive $S$ wave radial anisotropy down to $220-\mathrm{km}$ depth, indicating that SH wave velocity is larger than SV wave velocity, This observation is consistent with the assumption that flow directions both frozen in the lithosphere and active in the asthenosphere are horizontal. Rayleigh and Love waves average phase velocities at 110$\mathrm{km}$ depth are 4.1 and $4.5 \mathrm{~km} / \mathrm{s}$. Calculated average seismic properties at $1,300{ }^{\circ} \mathrm{C}$ and $3.63 \mathrm{GPa}$ (conditions estimated at 110-km depth; Figure 12) based on CPOs of the FN samples, which we interpret as fossil fabrics recording past asthenospheric flow, show, for a horizontal flow plane, average Rayleigh waves velocities of $4.3 \mathrm{~km} / \mathrm{s}$ and Love waves, of $4.5 \mathrm{~km} / \mathrm{s}$, that is, slightly faster or similar to the seismological observations. These predictions are also consistent with those of adjoint tomography models at 100-km depth in the study region ( 4.5 km/s; Colli et al., 2013).

The recent PILAB experiment provides higher resolution information on the seismic properties of the young equatorial Atlantic (crustal ages of 0-40 Ma) in the vicinity of the Romanche fracture zone. Surface wave imaging by Harmon et al. (2018) suggests a 60-km-thick fast lid with velocities of $4.62 \mathrm{~km} / \mathrm{s}$, which are in the upper range of the predicted $S$ wave velocities for the average FN peridotite (Figure 14). The radial anisotropy ( $\xi$, defined as the square of the ratio between Love- and Rayleigh-wave phase velocities) attains 1.08 in the upper $200 \mathrm{~km}$. This observation is coherent with the maximum $\xi$ value of $\sim 1.09$ calculated for the average FN peridotite considering a horizontal flow plane (Figure 14). Measured Rayleigh-wave azimuthal anisotropy attains $1-2 \%$ for the $2 \theta$ terms and shows no significant $4 \theta$ terms. This observation is consistent with the predicted S2-wave velocity anisotropy within a horizontal flow plane, which displays up to $2 \%$ of anisotropy with a $180^{\circ}$ periodicity (Figure 14 ). A vertical flow plane would result in higher anisotropy and more complex patterns for the azimuthal variation of Rayleigh-wave velocities. The analysis of SKS splitting data for this experiment (Kendall et al., 2017) implies that the fast $S$ wave polarization and, hence, the flow direction in the uppermost mantle are parallel to the direction of plate spreading.

In summary, the average seismic properties of FN mantle xenoliths are consistent with available seismological data in the equatorial Atlantic, if the foliation and lineation in lithospheric mantle are horizontal. This, together with the low-stress microstructures and CPO of the xenoliths, corroborates the model by which seismic anisotropy in the oceanic lithosphere and asthenosphere results essentially from horizontal shear in the asthenosphere, accommodated mainly by dislocation creep in olivine with dominant activation of the [100] (010) slip system, producing olivine CPO that are progressively fossilized in the lithosphere as the plate cools.

\section{Conclusions}

Integrated analysis of microstructures, crystal preferred orientations, chemical compositions, and equilibrium temperatures of Fernando de Noronha mantle xenoliths reveals that the oceanic lithosphere in the equatorial Atlantic has experienced high temperature deformation followed by variable degrees of annealing and multiple episodes of reactive melt percolation.

The microstructures and olivine CPOs are consistent with mantle deformation mainly accommodated by olivine $[100](010)$ dislocation creep at high-temperature, low-pressure, and low-stress conditions. Comparison of the seismic properties calculated based on the xenolith composition, $\mathrm{CPO}$, and equilibrium temperatures 
Acknowledgments

We thank the ICMBio and the Parque Nacional Marinho de Fernando de Noronha, Brazil, for the authorization for sampling within the limits of the park. C. Archanjo and M.H.B.M.

Hollanda are thanked for the assistance during fieldwork. Constructive reviews by G. Lloyd, A. Lee, and an anonymous reviewer are acknowledged. D. Delmas and C. Nevado prepared high-quality polished thin sections for EBSD measurements, which were performed with the assistance of F. Barou at the EBSDSEM INSU national facility at

Géosciences Montpellier (CNRS and Université de Montpellier). Electron microprobe analyses were carried out with the assistance of B. Boyer at the Service Microsonde Sud, Université de Montpellier. The China Scholarship Council funded S.L. during his 14month stay at Geosciences Montpellier. M.M. was supported by projects MIURPRIN 2005-2005049821 and 201720178LPCPW. The data used in this article are presented in the figures, tables, and supporting information. The raw EBSD data are available from the corresponding author upon request. to the seismological data in the equatorial Atlantic and thermal models suggests a $75-90-\mathrm{km}$-thick plate, with olivine CPO fossilized from horizontal asthenospheric flow in the direction of plate spreading leading to moderate seismic anisotropy. We propose therefore that the deformation recorded by the xenoliths mainly occurred in the asthenosphere in response to horizontal asthenospheric flow associated with the plate motion. Deformation gradually ceased as the plate cooled down and became thicker with time. The resulting CPOs were then frozen in the lithospheric mantle. High temperature in deep section of the lithosphere allowed nevertheless for annealing, which partially recovered the microstructures, but preserved the CPO. Cenozoic melt percolation resulted in localized reworking of the microstructure by recrystallization, probably under static conditions.

The studied peridotites have more fertile chemical compositions than abyssal peridotites from Mid-Atlantic Ridge (MAR). This difference may be partially explained by a lower degree of partial melting since FN xenoliths probably dominantly sample mantle sections accreted to the lithosphere by cooling far from the mid-ocean ridge. However, this process cannot explain the full range of compositions observed among FN peridotites. We invoke therefore two stages of melt-rock interaction, which affected the lithospheric mantle in a heterogeneous manner. First, continuous infiltration of small volumes of melt from asthenosphere into the base of the lithosphere, which probably decreased in intensity as the lithosphere became cooler and thicker away from the mid-ocean ridge. The second process is associated with reactive percolation of large volumes of melt associated with the volcanism and related dikes that formed the FN islands in the Cenozoic. This process results in more marked changes in composition, such as Fe enrichment, and in local recrystallization. However, it is a localized process, which only modifies the chemical composition and textures of the lithospheric mantle beneath the islands and in a spatially heterogeneous manner.

\section{Author Contributions}

A.T. conceived the project. A.T. and A.V. did the sampling. M.M. provided samples and geochemical data from a previous study. Data analyses were conducted by S.L. S.L. and A.T. wrote the article with contributions from all authors.

\section{References}

Abramson, E. H., Brown, J. M., Slutsky, L. J., \& Zaug, J. M. (1997). The elastic constants of San Carlos olivine to 17 GPa. Journal of Geophysical Research, 102(B6), 12,253-12,263. 10.1029/97JB00682

Anderson, O. L., Isaak, D., \& Oda, H. (1992). High-temperature elastic-constant data on minerals relevant to geophysics. Reviews of Geophysics, 30(1), 57-90. https://doi.org/10.1029/91RG02810

Bachmann, F., Hielscher, R., \& Schaeben, H. (2010). Texture analysis with MTEX-Free and open source software toolbox. Solid State Phenomena, 160, 63-68. https://doi.org/10.4028/www.scientific.net/SSP.160.63

Bachmann, F., Hielscher, R., \& Schaeben, H. (2011). Grain detection from 2d and 3d EBSD data-Specification of the MTEX algorithm. Ultramicroscopy, 111(12), 1720-1733. https://doi.org/10.1016/j.ultramic.2011.08.002

Baker, M. B., \& Stolper, E. M. (1994). Determining the composition of high-pressure mantle melts using diamond aggregates. Geochimica et Cosmochimica Acta, 58(13), 2811-2827. https://doi.org/10.1016/0016-7037(94)90116-3

Bodinier, J. L., Garrido, C. J., Chanefo, I., Bruguier, O., \& Gervilla, F. (2008). Origin of pyroxenite-peridotite veined mantle by refertilization reactions: Evidence from the Ronda peridotite (southern Spain). Journal of Petrology, 49(5), 999-1025. https://doi.org/10.1093/petrology/egn014

Bodinier, J. L., \& Godard, M. (2014). Orogenic, ophiolitic, and abyssal peridotites. In H. D. Holland \& K. K. Turekian (Eds.), Treatise on Geochemistry (2nd ed., pp. 103-167). Oxford: Elsevier.

Brey, G. P., \& Kohler, T. (1990). Geothermobarometry in four-phase lherzolites II. New thermobarometers, and practical assessment of existing thermobarometers. Journal of Petrology, 31(6), 1353-1378. https://doi.org/10.1093/petrology/31.6.1353

Bunge, H. J. (1982). Texture Analysis in Materials Science. London: Butterworth-Heinemann.

Chai, M., Brown, J. M., \& Slutsky, L. J. (1997). The elastic constants of an aluminous orthopyroxene to 12.5 GPa. Journal of Geophysical Research, 102(B7), 14,779-14,785. https://doi.org/10.1029/97JB00893

Colli, L., Fichtner, A., \& Bunge, H. P. (2013). Full waveform tomography of the upper mantle in the South Atlantic region: Imaging a westward fluxing shallow asthenosphere? Tectonophysics, 604, 26-40. https://doi.org/10.1016/j.tecto.2013.06.015

Doin, M. P., \& Fleitout, L. (1996). Thermal evolution of the oceanic lithosphere: An alternative view. Earth and Planetary Science Letters, 142(1-2), 121-136. https://doi.org/10.1016/0012-821x(96)00082-9

Drouin, M., Ildefonse, B., \& Godard, M. (2010). A microstructural imprint of melt impregnation in slow spreading lithosphere: Olivine-rich troctolites from the Atlantis Massif, Mid-Atlantic Ridge, 30N, IODP Hole U1309D. Geochemistry, Geophysics, Geosystems, 11, Q06003. https://doi.org/10.1029/2009GC002995

Frets, E., Tommasi, A., Garrido, C. J., Vauchez, A., Mainprice, D., Targuisti, K., \& Amri, I. (2014). The Beni Bousera peridotite (Morocco): An oblique-slip low-angle shear zone thinning the subcontinental mantle lithosphere. Journal of Petrology, 55, 283-313. https://doi.org/ 10.1093/petrology/egt067

Gaherty, J. B., Lizarralde, D., Collins, J. A., Hirth, G., \& Kim, S. (2004). Mantle deformation during slow seafloor spreading constrained by observations of seismic anisotropy in the western Atlantic. Earth and Planetary Science Letters, 228(3-4), 255-265. https://doi.org/ 10.1016/j.epsl.2004.10.026 
Godard, M., Jousselin, D., \& Bodinier, J. L. (2000). Relationships between geochemistry and structure beneath a palaeo-spreading centre: A study of the mantle section in the Oman ophiolite. Earth and Planetary Science Letters, 180(1-2), 133-148. https://doi.org/10.1016/ S0012-821x(00)00149-7

Harmon, N., Rychert, C. A., Agius, M. R., Tharimena, S., \& Kendall, J. M. (2018). Surface wave imaging of the lithosphere asthenosphere system beneath 0-80 My seafloor of the equatorial Mid-Atlantic Ridge from the PI-LAB experiment. Paper presented at the EGU general meeting, Vienna. Abstract EGU2018-16016. Retrieved from https://meetingorganizer.copernicus.org/EGU2018/EGU2018-16016.pdf

Heine, C., Zoethout, J., \& Muller, R. D. (2013). Kinematics of the South Atlantic rift. Solid Earth, 4(2), 215-253. https://doi.org/10.5194/se4-215-2013

Hess, H. H. (1964). Seismic anisotropy of the uppermost mantle under oceans. Nature, 203(4945), 629-631.

Hielscher, R., \& Schaeben, H. (2008). A novel pole figure inversion method: Specification of the MTEX algorithm. Journal of Applied Crystallography, 41(6), 1024-1037. https://doi.org/10.1107/S0021889808030112

Higgie, K., \& Tommasi, A. (2012). Feedbacks between deformation and melt distribution in the crust-mantle transition zone of the Oman ophiolite. Earth and Planetary Science Letters, 359-360, 61-72. https://doi.org/10.1016/j.epsl.2012.10.003

Higgie, K., \& Tommasi, A. (2014). Deformation of a partially molten mantle: Constraints from plagioclase-lherzolites from Lanzo, western Alps. Tectonophysics, 615-616, 167-181. https://doi.org/10.1016/j.tecto.2014.01.007

Isaak, D. G., Ohno, I., \& Lee, P. C. (2006). The elastic constants of monoclinic single-crystal chrome-diopside to 1,300 K. Physics and Chemistry of Minerals, 32(10), 691-699. https://doi.org/10.1007/s00269-005-0047-9

Jackson, J. M., Sinogeikin, S. V., \& Bass, J. D. (2007). Sound velocities and single-crystal elasticity of orthoenstatite to $1073 \mathrm{~K}$ at ambient pressure. Physics of the Earth and Planetary Interiors, 161(1-2), 1-12. https://doi.org/10.1016/j.pepi.2006.11.002

Kendall, J. M., Rychert, C., Harmon, N., Tharimena, S., \& Agius, M. R. (2017). Anisotropy of the upper mantle beneath the equatorial part of the Mid-Atlantic Ridge. Paper presented at the AGU Fall Meeting. Abstract S43D-2480. Retrieved from https://agu.confex.com/agu/ fm17/meetingapp.cgi/Paper/275481

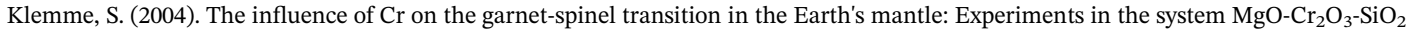
and thermodynamic modelling. Lithos, 77(1-4), 639-646. https://doi.org/10.1016/j.lithos.2004.03.017

Kogarko, L. N., Kurat, G., \& Ntaflos, T. (2001). Carbonate metasomatism of the oceanic mantle beneath Fernando de Noronha Island, Brazil. Contributions to Mineralogy and Petrology, 140(5), 577-587. https://doi.org/10.1007/s004100000201

Kostopoulos, D. K. (1991). Melting of the shallow upper mantle-A new perspective. Journal of Petrology, 32(4), 671-699. https://doi.org/ 10.1093/petrology/32.4.671

Le Roux, V., Bodinier, J. L., Tommasi, A., Alard, O., Dautria, J. M., Vauchez, A., \& Riches, A. J. V. (2007). The Lherz spinel lherzolite: Refertilized rather than pristine mantle. Earth and Planetary Science Letters, 259(3-4), 599-612. https://doi.org/10.1016/j. epsl.2007.05.026

Le Roux, V., Tommasi, A., \& Vauchez, A. (2008). Feedback between melt percolation and deformation in an exhumed lithosphereasthenosphere boundary. Earth and Planetary Science Letters, 274(3-4), 401-413. https://doi.org/10.1016/j.epsl.2008.07.053

Lissenberg, C. J., \& Dick, H. J. B. (2008). Melt-rock reaction in the lower oceanic crust and its implications for the genesis of mid-ocean ridge basalt. Earth and Planetary Science Letters, 271(1-4), 311-325. https://doi.org/10.1016/j.epsl.2008.04.023

Mainprice, D., Bachmann, F., Hielscher, R., \& Schaeben, H. (2014). Descriptive tools for the analysis of texture projects with large datasets using MTEX: Strength, symmetry and components. Geological Society, London, Special Publications, 409(1), 251-271. https://doi.org/ $10.1144 / \mathrm{sp} 409.8$

Mainprice, D., Hielscher, R., \& Schaeben, H. (2011). Calculating anisotropic physical properties from texture data using the MTEX opensource package. Geological Society, London, Special Publications, 360(1), 175-192. https://doi.org/10.1144/sp360.10

McKenzie, D. (1989). Some remarks on the movement of small melt fractions in the mantle. Earth and Planetary Science Letters, 95(1-2), 53-72. https://doi.org/10.1016/0012-821x(89)90167-2

Mehouachi, F., \& Singh, S. C. (2018). Water-rich sublithospheric melt channel in the equatorial Atlantic Ocean. Nature Geoscience, 11(1), 65-69. https://doi.org/10.1038/s41561-017-0034-z

Mercier, J. C. C., \& Nicolas, A. (1975). Textures and fabrics of upper-mantle peridotites as illustrated by xenoliths from basalts. Journal of Petrology, 16(2), 454-487. https://doi.org/10.1093/petrology/16.1.454

Mizusaki, A. M. P., Thomaz-Filho, A., Milani, E. J., \& de Césero, P. (2002). Mesozoic and Cenozoic igneous activity and its tectonic control in northeastern Brazil. Journal of South American Earth Sciences, 15(2), 183-198. https://doi.org/10.1016/S0895-9811(02)00014-7

Moulin, M., Aslanian, D., \& Unternehr, P. (2010). A new starting point for the south and equatorial Atlantic Ocean. Earth-Science Reviews, 98(1-2), 1-37. https://doi.org/10.1016/j.earscirev.2009.08.001

Nemčok, M., Henk, A., Allen, R., Sikora, P. J., \& Stuart, C. (2013). Continental break-up along strike-slip fault zones; observations from the equatorial Atlantic. Geological Society, London, Special Publications, 369(1), 537-556. https://doi.org/10.1144/sp369.8

Nimis, P., \& Grutter, H. (2010). Internally consistent geothermometers for garnet peridotites and pyroxenites. Contributions to Mineralogy and Petrology, 159(3), 411-427. https://doi.org/10.1007/s00410-009-0455-9

Niu, Y. L. (1997). Mantle melting and melt extraction processes beneath ocean ridges: Evidence from abyssal peridotites. Journal of Petrology, 38(8), 1047-1074. https://doi.org/10.1093/petrology/38.8.1047

O'Neill, H. S. C. (1981). The transition between spinel lherzolite and garnet lherzolite, and its use as a geobarometer. Contributions to Mineralogy and Petrology, 77(2), 185-194. https://doi.org/10.1007/Bf00636522

Perlingeiro, G., Vasconcelos, P. M., Knesel, K. M., Thiede, D. S., \& Cordani, U. G. (2013). Ar-40/Ar-39 geochronology of the Fernando de Noronha archipelago and implications for the origin of alkaline volcanism in the NE Brazil. Journal of Volcanology and Geothermal Research, 249, 140-154. https://doi.org/10.1016/j.jvolgeores.2012.08.017

Qi, C., Hansen, L. N., Wallis, D., Holtzman, B. K., \& Kohlstedt, D. L. (2018). Crystallographic preferred orientation of olivine in sheared partially molten rocks: The source of the "a-c switch". Geochemistry, Geophysics, Geosystems, 19, 316-336. https://doi.org/10.1002/ 2017GC007309

Ringwood, A. E. (1975). Composition and Petrology of the Earth's Mantle. New York: McGraw-Hill.

Rivalenti, G., Mazzucchelli, M., Girardi, V. A. V., Vannucci, R., Barbieri, M. A., Zanetti, A., \& Goldstein, S. L. (2000). Composition and processes of the mantle lithosphere in northeastern Brazil and Fernando de Noronha: Evidence from mantle xenoliths. Contributions to Mineralogy and Petrology, 138(4), 308-325. https://doi.org/DOI10.1007/s004100050565

Rollet, A., Rohrer, G. S., \& Humphreys, J. (2017). Recrystallization and Related Annealing Phenomena (3rd ed., p. 734). Amsterdam, Netherlands: Elsevier.

Rümpker, G., Tommasi, A., \& Kendall, J. M. (1999). Numerical simulations of depth-dependent anisotropy and frequency-dependent wave propagation effects. Journal of Geophysical Research, 104, 23,141-23,153. 
Rychert, C. A., Harmon, N., Tharimena, S., \& Kendall, J. M. (2018). $S$-to-P receiver function imaging of the 0-40 My old Atlantic Plate from the PI-LAB experiment. Paper presented at the EGU General Meeting, Vienna. Abstract 2018-16041. Retrieved from https://meetingorganizer.copernicus.org/EGU2018/EGU2018-16041.pdf

Sang, L. Q., \& Bass, J. D. (2014). Single-crystal elasticity of diopside to $14 \mathrm{GPa}$ by Brillouin scattering. Physics of the Earth and Planetary Interiors, 228, 75-79. https://doi.org/10.1016/j.pepi.2013.12.011

Silveira, G., \& Stutzmann, E. (2002). Anisotropic tomography of the Atlantic Ocean. Physics of the Earth and Planetary Interiors, 132(4), 237-248. https://doi.org/10.1016/S0031-9201(02)00076-6

Taylor, W. R. (1998). An experimental test of some geothermometer and geobarometer formulations for upper mantle peridotites with application to the thermobarometry of fertile Iherzolite and garnet websterite. Neues Jahrbuch Fur Mineralogie-Abhandlungen, 172(2-3), 381-408. https://doi.org/10.1127/njma/172/1998/381

Tommasi, A. (1998). Forward modeling of the development of seismic anisotropy in the upper mantle. Earth and Planetary Science Letters, 160(1-2), 1-13. https://doi.org/10.1016/S0012-821x(98)00081-8

Tommasi, A., Godard, M., Coromina, G., Dautria, J.-M., \& Barsczus, H. (2004). Seismic anisotropy and compositionally induced velocity anomalies in the lithosphere above mantle plumes: A petrological and microstructural study of mantle xenoliths from French Polynesia. Earth and Planetary Science Letters, 227(3-4), 539-556. https://doi.org/10.1016/j.epsl.2004.09.019

Tommasi, A., Mainprice, D., Canova, G., \& Chastel, Y. (2000). Viscoplastic self-consistent and equilibrium-based modeling of olivine lattice preferred orientations: Implications for the upper mantle seismic anisotropy. Journal of Geophysical Research, 105(B4), 7893-7908. https://doi.org/10.1029/1999JB900411

Tommasi, A., \& Vauchez, A. (2015). Heterogeneity and anisotropy in the lithospheric mantle. Tectonophysics, 661, 11-37. https://doi.org/ 10.1016/j.tecto.2015.07.026

Turcotte, D., \& Schubert, G. (2014). Geodynamics. Cambridge, UK: Cambridge University Press.

Vonlanthen, P., Kunze, K., Burlini, L., \& Grobety, B. (2006). Seismic properties of the upper mantle beneath Lanzarote (Canary Islands): Model predictions based on texture measurements by EBSD. Tectonophysics, 428(1-4), 65-85. https://doi.org/10.1016/j.tecto.2006.09.005

Walter, M. J. (1999). Comments on "Mantle melting and melt extraction processes beneath ocean ridges: Evidence from abyssal peridotites" by Yaoling Niu. Journal of Petrology, 40(7), 1187-1193. https://doi.org/10.1093/petroj/40.7.1187

Walter, M. J., Sisson, T. W., \& Presnall, D. C. (1995). A mass proportion method for calculating melting reactions and application to melting of model upper-mantle lherzolite. Earth and Planetary Science Letters, 135(1-4), 77-90. https://doi.org/10.1016/0012-821x(95)00148-6

Warren, J. M. (2016). Global variations in abyssal peridotite compositions. Lithos, 248-251, 193-219. https://doi.org/10.1016/j. lithos.2015.12.023

Wessel, P., \& Smith, W. H. F. (1991). Free software helps map and display data. Eos, Transactions American Geophysical Union, 72(41), 441-446. https://doi.org/10.1029/90EO00319 